\title{
6. DIAGENETIC DOLOMITE, CALCITE, RHODOCHROSITE, MAGNESITE, AND LANSFORDITE FROM SITE 799, JAPAN SEA-IMPLICATIONS FOR DEPOSITIONAL ENVIRONMENTS AND THE DIAGENESIS OF ORGANIC-RICH SEDIMENTS ${ }^{1}$
}

\author{
Ryo Matsumoto ${ }^{2}$
}

\begin{abstract}
Abundant and various diagenetic carbonates were recovered from a 1084-m-thick, Quaternary to lower Miocene section at ODP Site 799 in the Japan Sea. Petrographic, XRD, SEM, EDS-chemical, and isotopic analyses revealed wide variations in occurrence and textural relations and complex mineralogy and chemistry. Diagenetic carbonates include calcite, calcium-rich rhodochrosite, iron- and manganese-rich magnesite, iron- and manganese-rich dolomite and ankerite, and iron- and manganeserich lansfordite (hydrous $\mathrm{Mg}$-carbonate).

Rhodochrosite commonly occurs as small, solid nodules and semi-indurated, thin layers in bioturbated, mottled sediments of Units I and II (late Miocene to Quaternary). Lansfordite occurs as unindurated nodules and layers in Unit II (late Miocene and Pliocene), whereas magnesite forms indurated beds a few centimeters thick in slightly bioturbated-to-faintly laminated sediments of Unit III (middle and late Miocene). Some rhodochrosite nodules have dark-colored, pyritic cores, and some pyrite-rhodochrosite nodules are overgrown by and included within magnesite beds. Dolomite and ankerite tend to form thick beds $(>10 \mathrm{~cm})$ in bedded to laminated sediments of Units III, IV, and V (early to late Miocene). Calcite occurs sporadically throughout the Site 799 sediments.

The $\delta^{18} \mathrm{O}$ values of carbonates and the interstitial waters, and the measured geothermal gradient indicate that almost all of the Site 799 carbonates are not in isotopic equilibrium with the ambient waters, but were precipitated in the past when the sediments were at shallower depths. Depths of precipitation obtained from the $\delta^{18} \mathrm{O}$ of carbonates span from 310 to $510 \mathrm{mbsf}$ for magnesite and from 60 to $580 \mathrm{mbsf}$ for dolomite-ankerite. Rhodochrosite and calcite are estimated to have formed within sediments at depths shallower than 80 mbsf.

Diagenetic history in the Site 799 sediments have been determined primarily by the environment of deposition; in particular, by the oxidation-reduction state of the bottom waters and the alkalinity level of the interstitial waters. Under the well-oxygenated bottom-water conditions in the late Miocene and Pliocene, manganese initially accumulated on the seafloor as hydrogenous oxides and subsequently was mobilized and reprecipitated as rhodochrosite within the shallow sulfate-reduction, sub-oxic zone. Precipitation of lansfordite occurred in the near-surface sediments with abundant organic carbon and an extremely high alkalinity during the latest Miocene and Pliocene. The lansfordite was transformed to magnesite upon burial in the depth interval 310 to 510 mbsf. Dolomite first precipitated at shallow depths in Mn-poor, anoxic, moderately biocalcareous sediments of early to late Miocene. With increasing temperature and depth, the dolomite recrystallized and reequilibrated with ambient waters at depths below about $400 \mathrm{mbsf}$.
\end{abstract}

\section{INTRODUCTION}

Holes 799A and 799B, drilled in the center of Kita-Yamato Trough (Fig. 1) during Leg 128, penetrated a 1084-m-thick, Quaternary to lower Miocene section, which is dominantly composed of organic-carbonrich, diatomaceous siliceous sediments (Shipboard Scientific Party, $1990 \mathrm{a}, \mathrm{f}, \mathrm{g})$. Notably, the sediments contain abundant beds, layers, lenses, and concretions of diagenetic carbonates throughout the section. These carbonates are variable in mineralogy, chemistry, and isotopic composition, as well as their shape, thickness, diameter, induration, color, and textural relation with the surrounding sediments. Diagenetic carbonates recovered at Site 799 include calcite, rhodochrosite, magnesite, dolomite, and probable lansfordite, a hydrous $\mathrm{Mg}$ carbonate; among these, dolomite is most abundant, rhodochrosite and magnesite are common, and calcite and lansfordite are subordinate.

Deep-sea, diagenetic carbonates have increasingly been reported from the various continental margin and forearc sediments by DSDPODP drillings. Pisciotto and Mahoney (1981) and Kelts and McKenzie (1982) have found dią netic dolomite and calcite from the Neogene to Quaternary organic-carbon-rich, hemipelagic sediments in anoxic basins off Baja California and in the Gulf of California, respectively. Matsumoto and Matsuhisa (1985) recognized diagenetic dolomite, ankerite, calcite, and siderite in the Miocene to Pleistocene clay and

\footnotetext{
'Pisciotto, K. A., Ingle, J. C., Jr., von Breymann, M. T., Barron, J., et al,, 1992. Proc. ODP, Sci. Results, 127/128, Pt. 1: College Station, TX (Ocean Drilling Program).

${ }^{2}$ Geological Institute, University of Tokyo, Hongo, Tokyo, Japan.
}

diatomaceous clay of the inner slope of Japan Trench. These deep-sea diagenetic carbonates have been explained as being formed in anoxic sediments with excess alkalinity during early diagenesis.

Dolomite beds and concretions are common in the Miocene to Pliocene siliceous sediments exposed at nearby land sections in northern Japan (On'nagawa and Funakawa Formations and their equivalents) (e.g., Matsumoto and Matsuda, 1987). Miocene Monterey Formation in California also contains numerous dolomite beds and concretions (e.g., Murata et al., 1969, 1972; Garrison and Graham., 1984; Kastner et al., 1984). Thus, the diagenetic dolomite is rather common in the Neogene biosiliceous sediments of the circum-Pacific region, and the presence of abundant dolomites in the organic-matter rich, sediments at Site 799 is not surprising.

In contrast, occurrence of rhodochrosite, and particularly magnesite and lansfordite, is a unique feature of Site 799 diagenetic carbonates. Rhodochrosite and Mn-bearing carbonates have been sporadically reported from several DSDP/ODP Sites (e.g., Wada et al., 1982; von Rad and Bots, 1987; Bohrmann and Thiede, 1989). Mn-bearing calcite and dolomite are common in the on-land exposed sections of the Miocene siliceous sediments in northern Japan (e.g., Taguchi et al., 1980; Matsumoto and Matsuda, 1987), however, the origin of manganese of the Mn-bearing carbonates has frequently been ascribed to hydrothermal activity and volcanism. The lithologic association of the rhodochrosite in Site 799 sediments appears to exclude this interpretation. Mn-bearing carbonates are often associated with $\mathrm{Fe}$ bearing carbonates and/or siderite (Matsumoto and Matsuhisa, 1980; Matsumoto and Matsuda, 1987), but siderite has not been detected in Site 799 sediments. 


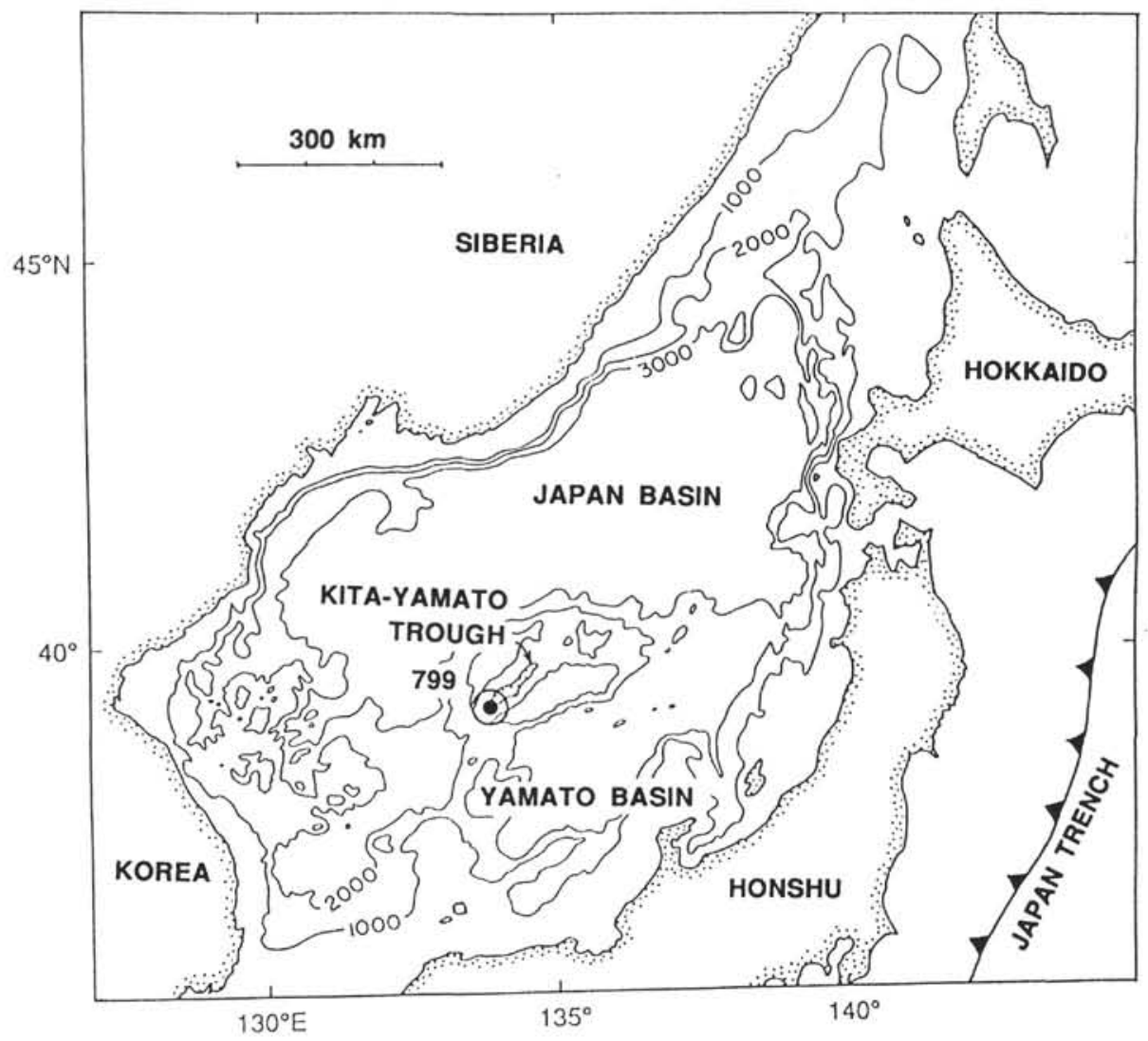

Figure 1. Location of Site 799 in the Kita-Yamoto Trough, Japan Sea.

The unusual occurrence of magnesite and lansfordite in normal marine sediments at Site 799 is really surprising, poses an interesting interpretation problem. Magnesite is usually considered to be either an evaporite mineral precipitated from concentrated seawater or, alternatively, an alteration-weathering product of mafic-ultramafic igneous rocks. At Site 799, lithologic and paleontologic evidence seem to rule out these mechanisms for the precipitation of magnesite and lansfordite. Comparatively rare but coexisting rhodochrosite and magnesite suggest unusual depositional and/or diagenetic environments.

Another important characteristic of Site 799 carbonates is the apparent stratigraphic control on the distribution of diagenetic carbonates such as lansfordite in Pliocene sediments, rhodochrosite and calcite in Pliocene and upper Miocene sediments, magnesite and dolomite in upper and middle Miocene sections. This apparent distribution pattern may be related to past fluctuations in bottom water conditions and changing rates of surface water productivity, which together reflect changes in the paleoceanography of the proto-Japan Sea. Alternatively, the stratigraphically controlled distribution may be explained as the result of diagenetic modification of carbonates and reflect the evolution of the interstitial water chemistry, and temperature increase with depth.

The purpose of this article is to document the occurrence and mineralogy of diagenetic carbonates at Site 799 in the failed rift basin in the center of the Japan Sea, and to use textural relations, lithologic associations, geochemistry, and isotopic data to decipher the cause and unusual environmental conditions that may have given rise to such a unique assemblage of diagenetic carbonates.

\section{LITHOLOGIC DESCRIPTION}

The 1084-m-thick section penetrated at Site 799 is composed dominantly of biosiliceous components, deposited at lower to bathyal water depths (Shipboard Scientific Party, 1990a, f, g). The section has been divided into five lithologic units according to the major lithology, sedimentary structures, and diagenetic modifications (Fig. 2).

\section{Unit I (0-170 mbsf, Quaternary to late Pliocene)}

Unit $\mathrm{I}$ is mainly composed of diatomaceous ooze and clay and terrigenous clay and silty clay with minor turbidite units of siliciclastic and foraminifer sands. Intervals of slump deposits with harmonic and disharmonic folds are conspicuous. The upper $117-\mathrm{m}$ section is characterized by distinctive light/dark rhythms, made up of light-colored, homogeneous to burrowed intervals interbedded with dark-colored, thinly laminated intervals. The organic carbon content exhibits extreme fluctuations between $0.2 \%$ in the lightcolored intervals and $5.6 \%$ in the dark-colored intervals. Bioturbation and burrowed sediments are not common throughout Unit I, suggesting that the Unit I sediments were deposited under comparatively dysaerobic conditions.

\section{Unit II (170-457 mbsf, late Pliocene to late Miocene)}

Sediments of Unit II comprise homogeneous to mottled diatomaceous ooze, clayey diatomaceous mixed sediments, and diatomaceous mixed clay with increasing amounts of biosiliceous components. The organic carbon content is mostly less than $1.5 \%$. Deposition of Unit II in the oxygenated bottom water has been suggested by the moderate-to-intensive bioturbation throughout.

\section{Unit III (457-800 mbsf, late to middle Miocene)}

Unit III consists of siliceous claystone and porcellanite. The upper 130 -m-thick part is characterized by decimeter-thick alternations of 

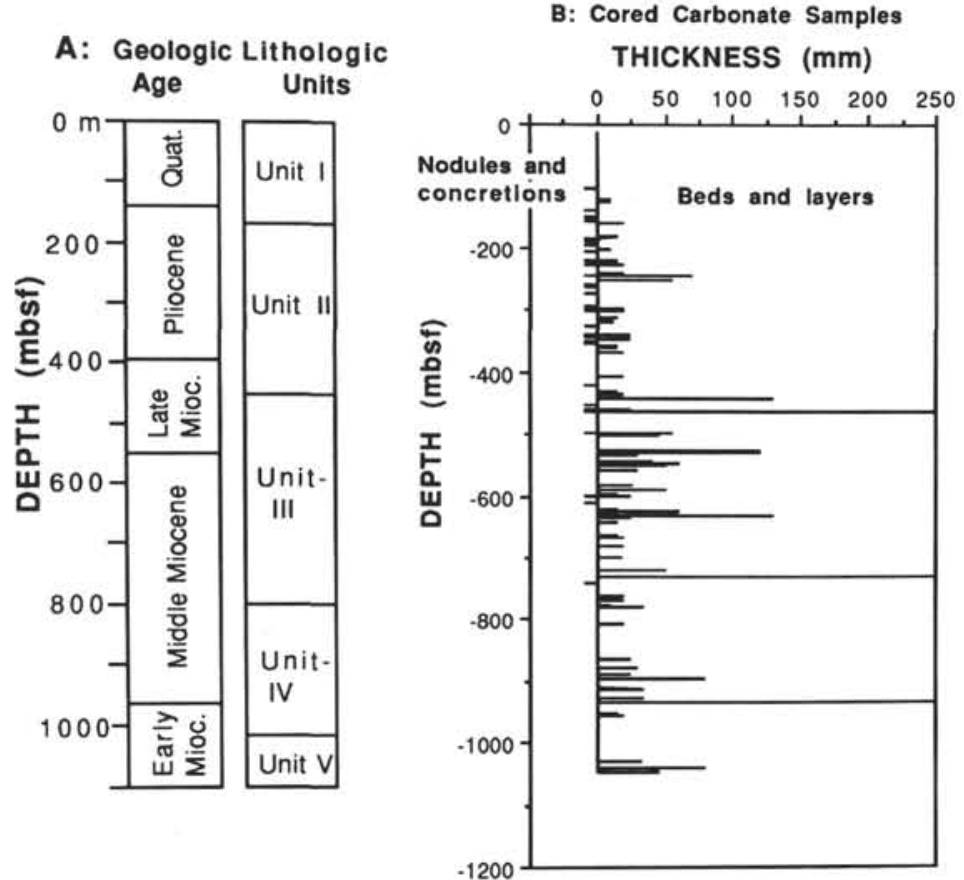

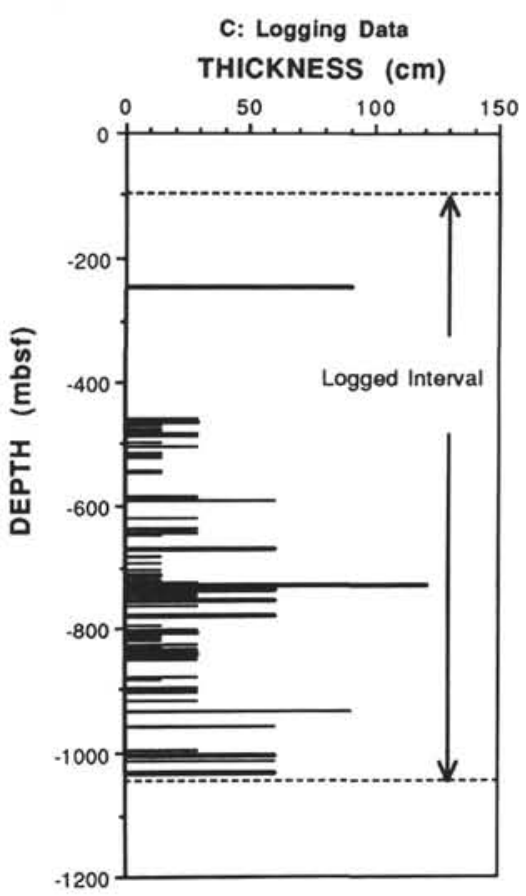

Figure 2. A. Stratigraphy and lithologic units at Site 799. B. Distribution and occurrence of diagenetic carbonates in Site 799 sediments. Concretions include nodules and patches, and layers, lenses, and beds are likewise grouped together. C. Carbonate layers determined from the results of natural gamma-ray, resistivity, and velocity logs.

light-colored, bioturbated intervals and dark-colored, laminated intervals. Sediments of this upper part, particularly the dark-colored intervals, contain abundant organic carbon, up tp 5.66\%. In contrast, the lower part of Unit III is dominated by bioturbated and burrowed sediments with decreasing amounts of organic carbon, averaging about $2 \%$. Flattened burrows and horizontal deposit-feeding burrows, which look like planar laminae, become more common with depth. This indicates that the upper middle and lower upper Miocene sediments accumulated under less oxygenated conditions than the middle Miocene sediments.

\section{Unit IV (800-1020 mbsf, middle to early Miocene)}

Unit IV is characterized by finely laminated to thin-bedded siliceous claystone and porcellanite with carbonate-rich, thin laminae. Millimeter to approximately 30 -cm-thick beds of glauconitebearing, siliciclastic sands, interpreted to be turbidites, are common throughout Unit IV. A partly altered, 20-m-thick rhyolitic tuff occurs in the basal part of Unit IV. Anoxic conditions probably prevailed during the deposition of Unit IV, as indicated by a lack of bioturbation and burrowing.

\section{Unit V (1020-1084 mbsf, early Miocene)}

Unit V sediments are composed of siliceous claystone and claystone intercalated with centimeter to approximately 5 -m-thick units of coarse-grained sands and sandstones. The sands and sandstones exhibit normal graded bedding, and contain shallow-water benthic foraminifers, wood fragments, plant debris, and calcareous shell fragments. Scattered bioturbation occurs.

Based on temperature measurements for the depth interval of 39.5 to $174.5 \mathrm{mbsf}$, the geothermal gradient of $98^{\circ}(\mathrm{C} / \mathrm{km}$ at Site 799 has been calculated (Shipboard Scientific Party, 1990a, f, g). Assuming that the gradient can be extrapolated to the bottom of the hole, the temperature at the bottom is calculated as approximately $106^{\circ} \mathrm{C}$.
Biosiliceous sediments at Site 799 are considered to have been originally composed predominantly of diatom frustules, which are absent from the siliceous sediments below $457 \mathrm{mbsf}$ due to silica diagenesis. Biogenic silica, opal-A, has been completely transformed to opal-CT below this depth, and Opal-CT transforms to quartz by $585 \mathrm{mbsf}$. Note that well-preserved diatom frustules were recognized within carbonate concretions and layers in opal-CT and diagenetic quartz zones. These occurrences suggest that carbonate cementation protects the frustules from dissolution prior to silica diagenesis as will be discussed later.

\section{SAMPLES AND METHODS}

Seventy diagenetic carbonate samples from Hole 799A and eightyfive from Hole 799B, including concretions, layers, and beds of various thicknesses, were collected on board the JOIDES Resolution for the present study. Selected concretion samples and comparatively thick carbonate beds were cut into vertical slabs and split into several subsamples for examination of the compositional gradient across the specimen. X-ray-diffraction analyses (XRD) were made on numerous carbonate samples and subsamples, using a Rigaku diffractometer with a nickel-filtered, $\mathrm{CuK} \alpha$ radiation of $30 \mathrm{KV} / 15 \mathrm{~mA}$. For selected samples, special XRD patterns were produced for the determination of the d(104) spacing of the carbonates with a scanning speed of $0.5 \% \mathrm{~min}$. The relative amounts of calcite, dolomite, rhodochrosite, and magnesite were estimated from the peak heights for the $d(104)$ spacing between about $29.5^{\circ}$ and $32.5^{\circ}(2 \theta)$. The amount of lansfordite was determined from the peak height of $\mathrm{d}(100)$ at about $31.5^{\circ}(2 \theta)$.

Textural relations and the microstructures of carbonates were observed under a light microscope and a Hitachi S-700 scanning electron microscope (SEM). Concentrations of $\mathrm{Ca}, \mathrm{Mg}, \mathrm{Mn}$, and $\mathrm{Fe}$ in the carbonate phases were determined for selected samples by means of a JEOL SEM equipped with a Kevex EDS system. The $\mathrm{CO}_{2}$ contents of the phases were calculated from the concentrations of cations, assuming stoichiometry. All analyses with a calculated total 
weight percent of $95 \%-105 \%$ were used and transformed into the molar percentage after $100 \%$ normalization. The identification of carbonate phases for some samples could be made only by combination of the results of XRD and EDS analyses, particularly for calcian rhodochrosite and breunnerite (ferroan magnesite), which have a spacing d(104) similar to ankerite and siderite, respectively.

Carbon and oxygen isotope analyses were performed using the method of McCrea (1950). Pulverized carbonate samples were reacted with $100 \%$ phosphoric acid at $25^{\circ} \mathrm{C}$ for about $15 \mathrm{hr}$ for calcite, 7 days for dolomite, and 30 days for magnesite and lansfordite. Separation of the $\mathrm{CO}_{2}$ gas from different carbonate phases in multicarbonate samples was made by a chemical leaching method (Matsumoto and Matsuda, 1987) based on the different reaction rates of different carbonate phases with $100 \%$ phosphoric acid at $25^{\circ} \mathrm{C}$. Uncertainties of the leaching method were tested by analyzing duplicate $\mathrm{CO}_{2}$ gases extracted from a single multicarbonate sample. The replicate measurements generally agree to better than $0.5 \%$. Isotopic analysis of the separated $\mathrm{CO}_{2}$ gas were measured on a Finnigan-Mat Delta E mass spectrometer against working reference gas prepared from Solenhofen limestone. The measured oxygen isotope ratios were corrected for the effect of acid fractionation at $25^{\circ} \mathrm{C}$. The phosphoric acid fractionation factors $\left(10^{3} \ln \alpha_{\mathrm{CO},-\mathrm{MCO}}\right)$ used for calcite were 10.20; for dolomite, 11.03; and for rhodochrosite, 10.07 (Friedman and O'Neil, 1977). The fractionation factor for magnesite at $50^{\circ} \mathrm{C}, 11.53$, was used for both magnesite and lansfordite, as the factors at $25^{\circ} \mathrm{C}$ were not known for these minerals. All results are reported as per mil values in the $\delta$-notation relative to the PDB international standard. Experimental error using normal procedures is less than $\pm 0.05 \%$ or $\delta^{13} \mathrm{C}$ and $\pm 0.1 \%$ o for $\delta^{18} \mathrm{O}$.

\section{RESULTS}

\section{Occurrence and Distribution of Carbonates}

\section{Biogenic Carbonates}

Biogenic calcium carbonates, largely in the form of foraminifers and nannofossils, commonly occur throughout Unit I (0-170 mbsf), especially above $100 \mathrm{mbsf}$, with the amounts being up to $40 \%$ by volume as estimated from smear slides. Foraminifers usually occur as sparse millimeter-thick, normally-graded, resedimented layers within the dark, laminated intervals. Below $100 \mathrm{mbsf}$, they are increasingly recrystallized and dissolved and their amounts diminish abruptly with depth. Foraminifers disappear at $182 \mathrm{mbsf}$ and nannofossils at 247 mbsf. Trace amounts of foraminifers and nannofossils reappear between 346 and $356 \mathrm{mbsf}$, indicating that the distribution of biogenic carbonates was controlled primarily by the composition of the accumulated sediments and secondarily by recrystallization and dissolution with depth. Sediments from this latter depth interval may have originally been more calcareous. Well-preserved shells of foraminifers, which are entirely filled and replaced by diagenetic carbonates, are recognized in some carbonate concretions and beds. This also indicates that a significant amount of biogenic carbonate was originally contained throughout the Site 799 sediments.

\section{Diagenetic Carbonates}

Diagenetic carbonates at Site 799 occur as (1) semi-indurated, chalky beds and lenses; (2) small, well-lithified, solid nodules; (3) variably lithified, millimeter-thick laminations ; (4) thin- to thick-bedded, welllithified layers and lenses; (5) Cement in sandstones; and (6) disseminated carbonate crystals. Carbonate layers and laminations may represent nodules or lenses, but are unrecognizable due to the fact that the drill hole is $6 \mathrm{~cm}$ in diameter, and the continuation of the beds cannot be traced beyond this limit. The term "carbonate layers" is used in this report to collectively denote laminations and beds, whereas the term "concretions" denotes lenses and nodules. The distribution of various categories of diagenetic carbonates is discussed below.

1. Semi- to slightly indurated lenses and chalky layers are characteristic of the bioturbated, burrowed, and mottled diatomaceous sediments of Unit II. The lenses are irregularly shaped, mostly between 0.5 and $5 \mathrm{~cm}$ in diameter, and olive yellow to yellow in color. Some lenses show coarser appearances produced by common inclusions of fairly hard, yellowish gray to dark gray, microconcretions a few millimeters in diameter. The chalky layers are pale olive to olive yellow, mostly 2 to $5 \mathrm{~cm}$ thick. Color gradations toward the overlying and underlying host sediments are visible.

2. The well-lithified, solid nodules, mostly ranging from 0.5 to $4 \mathrm{~cm}$ in diameter, include two varieties; light gray, angular to subrounded nodules, which tend to be concentrated in the bioturbated sediments of Unit II, and spheroidal to oval, composite nodules with an olive yellow carbonate rim and light gray core of concentrated pyrite characteristic for Units III and IV (Fig. 3). Differential compaction of sedimentary laminae is common around the composite nodules.

3. Thin layers (laminations), mostly 2 to $5 \mathrm{~mm}$ thick, of diagenetic carbonates commonly occur in bedded intervals at about 500 to 600 mbsf in Unit III and in Unit IV (Fig. 4). They exhibit differential compaction around the carbonate concretions. Although fragments of diagenetic carbonates are recognized in carbonate laminations, particularly in Unit IV, textural similarities seem to indicate that some of the carbonate laminations were inherited from sedimentary laminations, which were originally composed of foraminifer sands.

4. Hard and strongly indurated layers (beds) of carbonates, light gray to light greenish gray in color and 3 to $54 \mathrm{~cm}$ in thickness, were first encountered at $247 \mathrm{mbsf}$ in Unit III and occur commonly below approximately $450 \mathrm{mbsf}$ in Units III and IV. Probably because of the lithification contrast between the carbonate layers and the enclosing sediments, thick carbonate layers were often recovered as broken pieces; the tops and/or bottoms of large specimens $(>20 \mathrm{~cm})$ were broken. Therefore, thick indurated carbonate layers are possibly much thicker than those recovered. Uncompressed, well-preserved burrows and traces of bioturbation are clearly observed in several carbonate layers, indicating that the thick indurated layers were formed in soft sediments prior to significant compaction. A hard layer at $460 \mathrm{mbsf}$ at the top of Unit III includes nodules having distinctive zonal structure and exhibits differential compaction around the nodules (Fig. 5).

5. Turbidite layers, 1.5 to $3 \mathrm{~cm}$ thick, of fine to medium-grained volcanic sandstone at 1049 mbsf in Unit $\mathrm{V}$ are variably cemented by calcite. Some lithic fragments and feldspars are partly to completely replaced by calcite.

6. Disseminated rhombs of diagenetic carbonates occur in all five lithologic units, but the amounts are at most $10 \%$, usually less than $3 \%$ of the sediments.

Figure 2B summarizes the distribution of carbonate nodules and layers sampled for this study. Carbonate nodules and lenses are abundant in Unit II, but rare in Unit III and absent in Units IV and V. Relatively thin carbonate layers occur throughout, but thicker layers are present in the sediments below 450 mbsf.

\section{Carbonate Intervals Determined from Logging Data}

At Site 799, wireline logs were performed to measure the natural gamma ray, resistivity, sonic velocity, and geochemical properties for the depth interval of 100-1040 mbsf. Carbonate rocks generally have lower gamma ray, higher resistivity, and higher sonic velocity values compared with the surrounding shale and mudstone. Therefore, the presence of carbonate intervals can be interpreted based on the integrating gamma ray, resistivity, and velocity logs, and the geochemical logs for $\mathrm{Mg}$ and $\mathrm{Ca}$ concentrations. Figure $2 \mathrm{C}$ illustrates the 
$\mathrm{cm}$

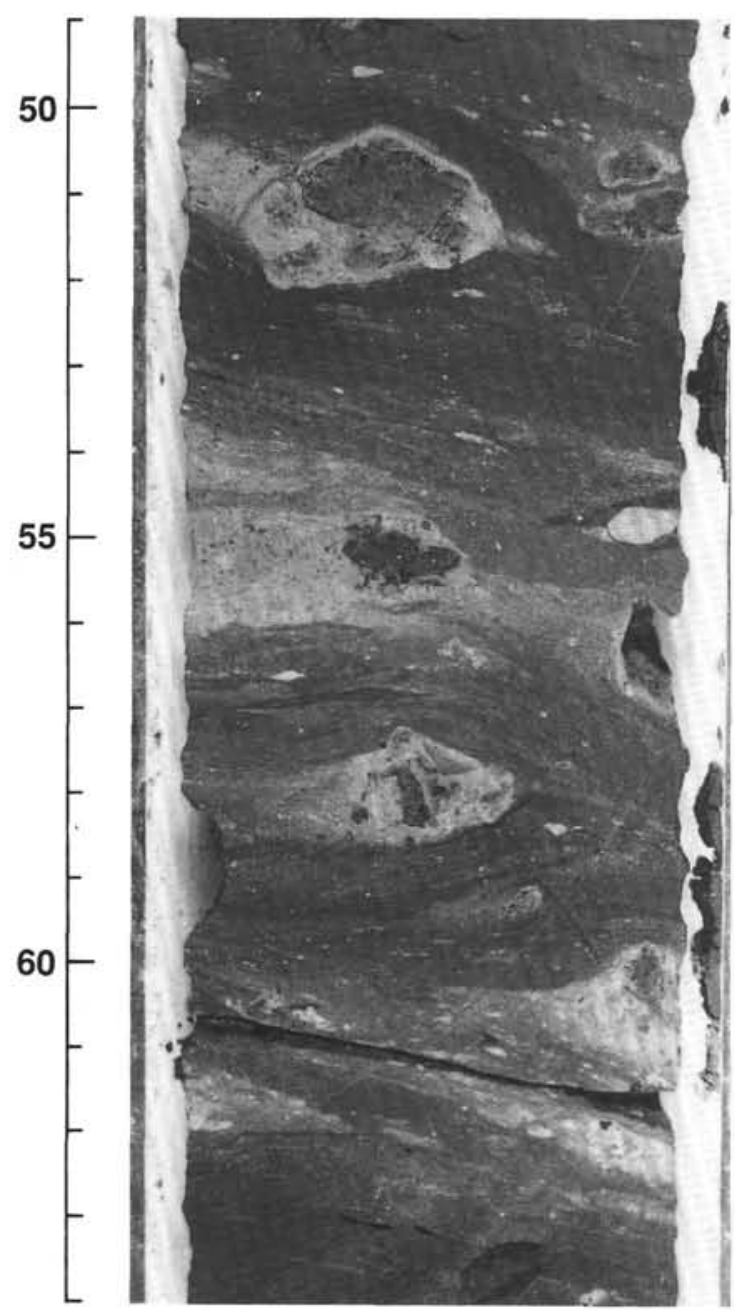

Figure 3. Composite nodules of a dark-colored, oxidized pyrite core and light-colored, rhodochrosite rind. Sedimentary laminae are bent around the nodules due to differential compaction (core photograph 128-799B-18R-5, $49-64 \mathrm{~cm})$.

occurrence of carbonate intervals determined from the logging data. The thickness of the carbonate intervals was read from the half-height width of peaks recorded on the resistivity log.

For the thicker carbonate intervals, the distribution pattern obtained from the logging data is remarkably similar to that observed in the cores, although the thicknesses are quite different. This variation stems from the breakage of the thick and hard carbonate layers during drilling, and the uncertainty of thickness estimation from the log plots. For example, a 7-cm thick cored layer at $247 \mathrm{mbsf}$ corresponds to an approximately 90 -cm-thick interval in the logs; a 35-cm-thick cored layer at $466 \mathrm{mbsf}$ to 30 -cm-thick interval in the logs; a 54-cm-thick cored layer at $730 \mathrm{mbsf}$ to 120 -cm-thick interval on the logs; and a 50-cm-thick cored layer at 934 mbsf to a 90 -cm-thick interval on the logs.

Carbonate layers thinner than approximately $50 \mathrm{~cm}$ are apparent on the logs, but were not always recovered by drilling. In contrast, above $450 \mathrm{mbsf}$ a few-centimeter-thick carbonate layers and nodules and lenses are abundant to common in Unit II of Hole $799 \mathrm{~A}$, but the loggings suggest only one thick carbonate interval. This difference probably reflects the difficulty of resolving thin layers by means of logs.

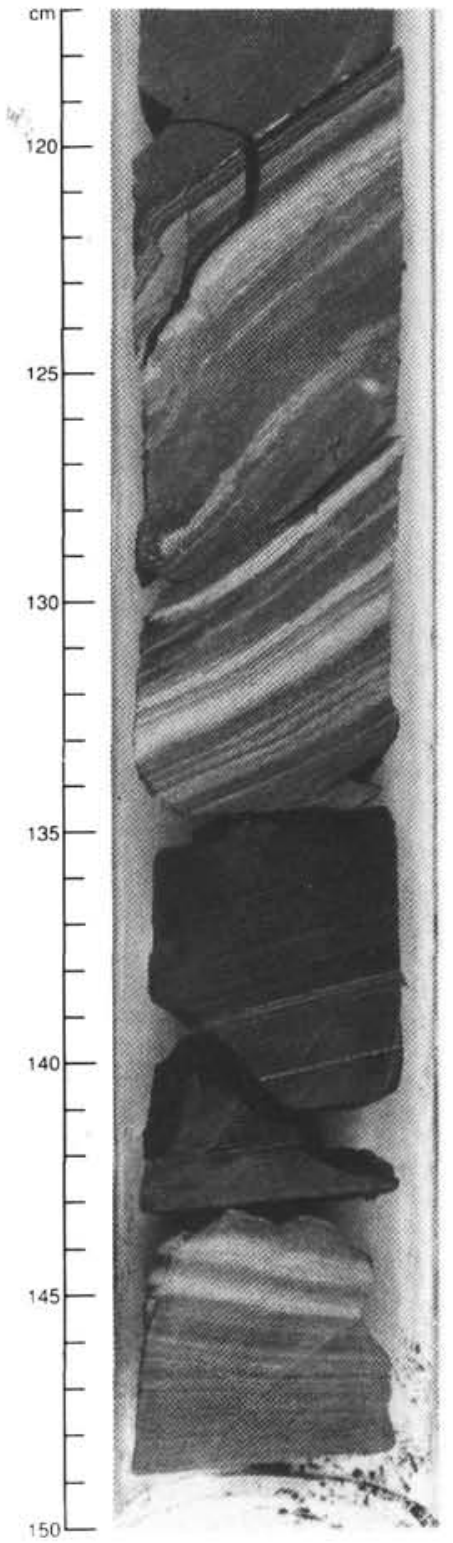

Figure 4. Thin, light-colored laminations of diagenetic dolomite within darkcolored siliceous claystone (core photograph 128-799B-47R-2, 117-150 cm).

\section{Mineralogy \\ Identification of Carbonate Phases}

Diagenetic carbonates encountered in the Site 799 sediments include calcite, dolomite, rhodochrosite, magnesite, and lansfordite. Identification of these minerals could not be achieved by XRD analysis alone, because the $\mathrm{d}(104)$ spacings of the carbonates are highly variable due to high degree of chemical substitution and different carbonate phases occasionally have similar d(104) spacings (Fig. 6).

The strongest diffraction peak of stoichiometric dolomite occurs at $31.0^{\circ}(2 \theta, \mathrm{CuK} \alpha)$, but dolomites peak at about $30.5^{\circ}-30.7^{\circ}$, due to the substitution of $\mathrm{Mg}$ by $\mathrm{Mn}$ and/or Fe. On the other hand, stoichio-metric rhodochrosite has its major peak at $32.5^{\circ}$, whereas rhodochrosite appears at about $31^{\circ}$, very close to the dolomite peak, and could be misidentified as dolomite without the chemical composition data obtained from EDS analyses. The shape of the d(104) peaks 

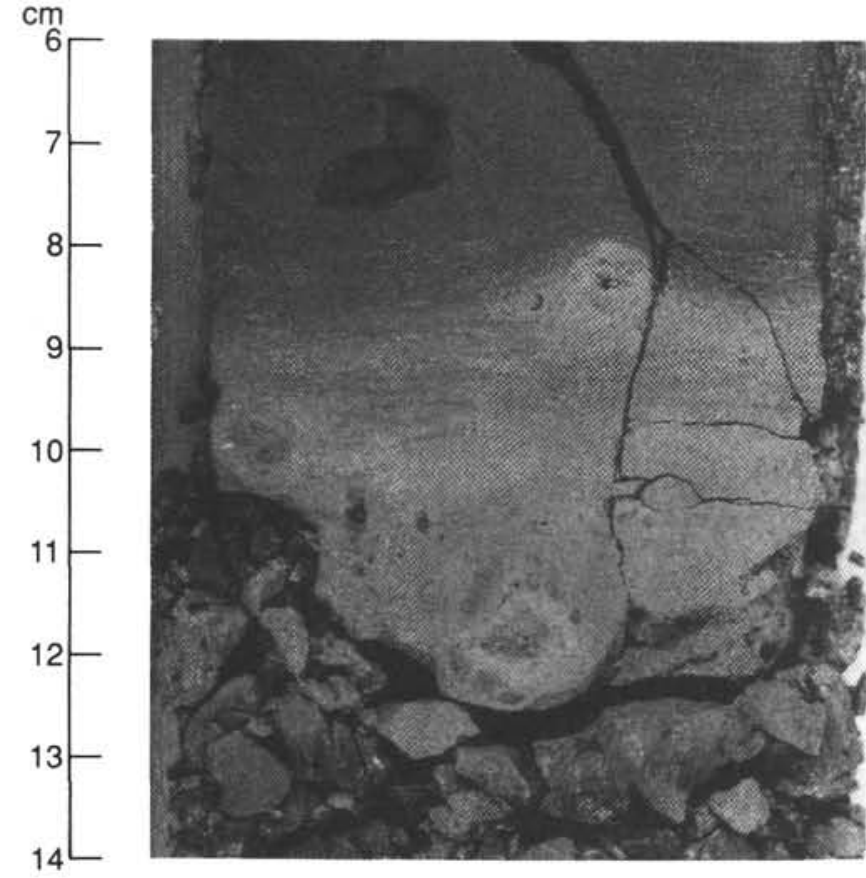

Figure 5. Composite nodules with a dark-gray, pyrite core and light-colored, rhodochrosite rind are included in a well-indurated, magnesite-rhodochrosite layer. Note the differential compaction around the nodules (core photograph 128-799A-50X-6, 6-14 cm).

of the Site 799 dolomite and rhodochrosite are, however, different, as shown in Figure 6; the dolomite peak is usually sharp and narrow, whereas rhodochrosite has a broad peak. This difference probably indicates that rhodochrosite contained in a single sample has a wider range in chemical composition than the dolomite in a single sample.

A diffraction peak occurs at about $32^{\circ}(2 \theta \mathrm{CuK} \alpha)$, where siderite appears, but siderite was not recognized in the EDS studies of the Site 799 sediments. Magnesite has a fairly sharp peak appearing at about $31.7^{\circ}(2 \theta)$ because of iron and manganese substitution. Bulk chemical analyses of selected carbonate layers in Unit II revealed high concentrations of magnesium and the volatile components $\left(\mathrm{H}_{2} \mathrm{O}+\mathrm{CO}_{2}\right)$, indicating the presence of $\mathrm{Mg}$-bearing carbonates, but the position of the strongest peak for this mineral appears at a systematically lower angle than for magnesite. EDS analyses of this mineral was not positive, presumably because of a high concentration of water in the mineral. The Mg-bearing carbonate has been tentatively identified as lansfordite $\left(\mathrm{MgCO}_{3} \cdot 5 \mathrm{H}_{2} \mathrm{O}\right)$. Figure 7 illustrates the peak shifts of lansfordite and magnesite. Lansfordite occurs from 150 to $436 \mathrm{mbsf}$, whereas magnesite is mostly between 434 and 660 mbsf. Two samples at 433.79 and 436.21 mbsf contain both lansfordite and magnesite. This relationship strongly suggests that hydrated lansfordite was dehydrated and recrystallized with depth and changed to magnesite by the burial depth of about $440 \mathrm{mbsf}$.

\section{Stratigraphic Control on the Distribution of Carbonates}

The distribution of the carbonate minerals throughout the Site 799 sediments is shown in Figure 8, where the amount of each is represented by the peak-height of the respective strongest diffraction peaks. The actual carbonate contents of the samples are, however, roughly estimated to be $10 \%$ to $20 \%$ by volume for calcite, $5 \%$ to $40 \%$ for rhodochrosite, $10 \%$ to $20 \%$ for lansfordite, $5 \%$ to $60 \%$ for magnesite, and $10 \%$ to $90 \%$ for dolomite.

$\mathrm{X}$-ray-detectable, diagenetic calcite first appears at $105 \mathrm{mbsf}$ and continues in sporadic occurrence down to $600 \mathrm{mbsf}$, in the middle of

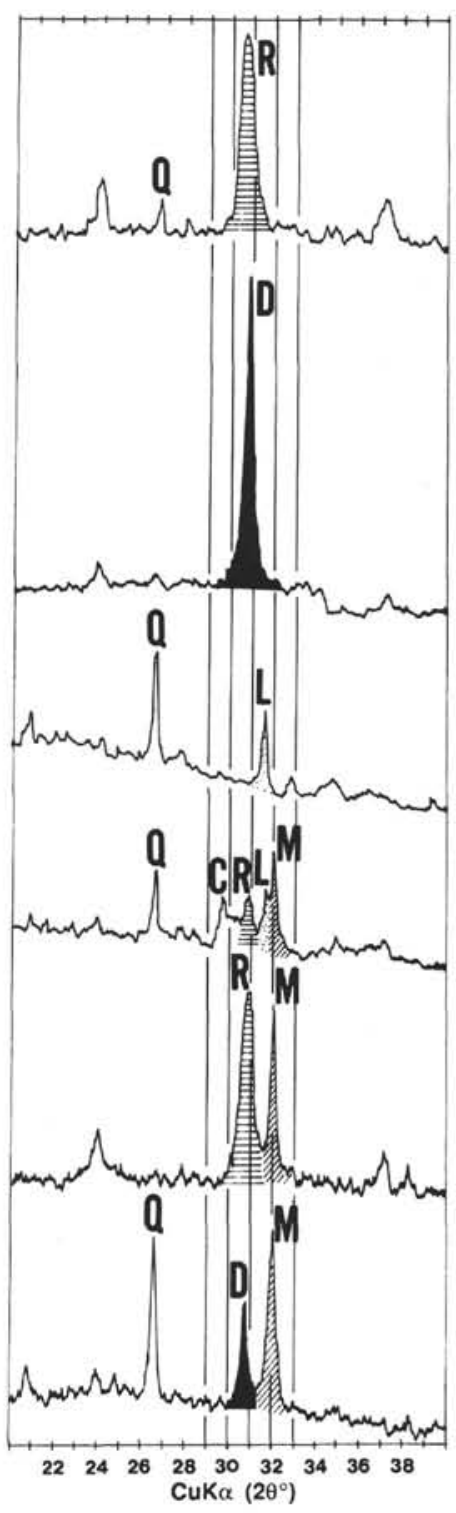

Figure 6. X-ray diffractograms showing the shape and position of the strongest peaks of dolomite (D), rhodochrosite (R), lansfordite (L), magnesite (M), calcite (C), and quartz (Q). Rhodochrosite is not always discriminated from dolomite, without EDS-chemical analyses.

Unit III. Rhodochrosite occurs predominantly as solid nodules and thin layers between 100 to $730 \mathrm{mbsf}$, but the amount tends to decrease below $450 \mathrm{mbsf}$. Lansfordite occurs as lenses and layers between 123 and 436 mbsf. Magnesite occurs either as chalky layers or hard layers below 436 mbsf or as deep as 920 mbsf in Unit IV, but is most concentrated between 440 and 650 mbsf.

The thick, hard dolomite layers were first encountered at $247 \mathrm{mbsf}$, but the continuous and common occurrence of dolomite begins at about 450 mbsf. Almost all of the thick carbonate layers below this depth and any layers below 750 mbsf are composed of dolomite; dolomite contents of the layers reaches up to $90 \%$ by volume.

Multicarbonate rocks composed of calcite, rhodochrosite, and magnesite (or lansfordite) are common in Units II and III at this site. They may form composite layers, concretions, or occur as homogeneous mixtures. In contrast, dolomite tends to occur substantially as monocarbonate layers which contain only a minimum amount of subordinate carbonates. 


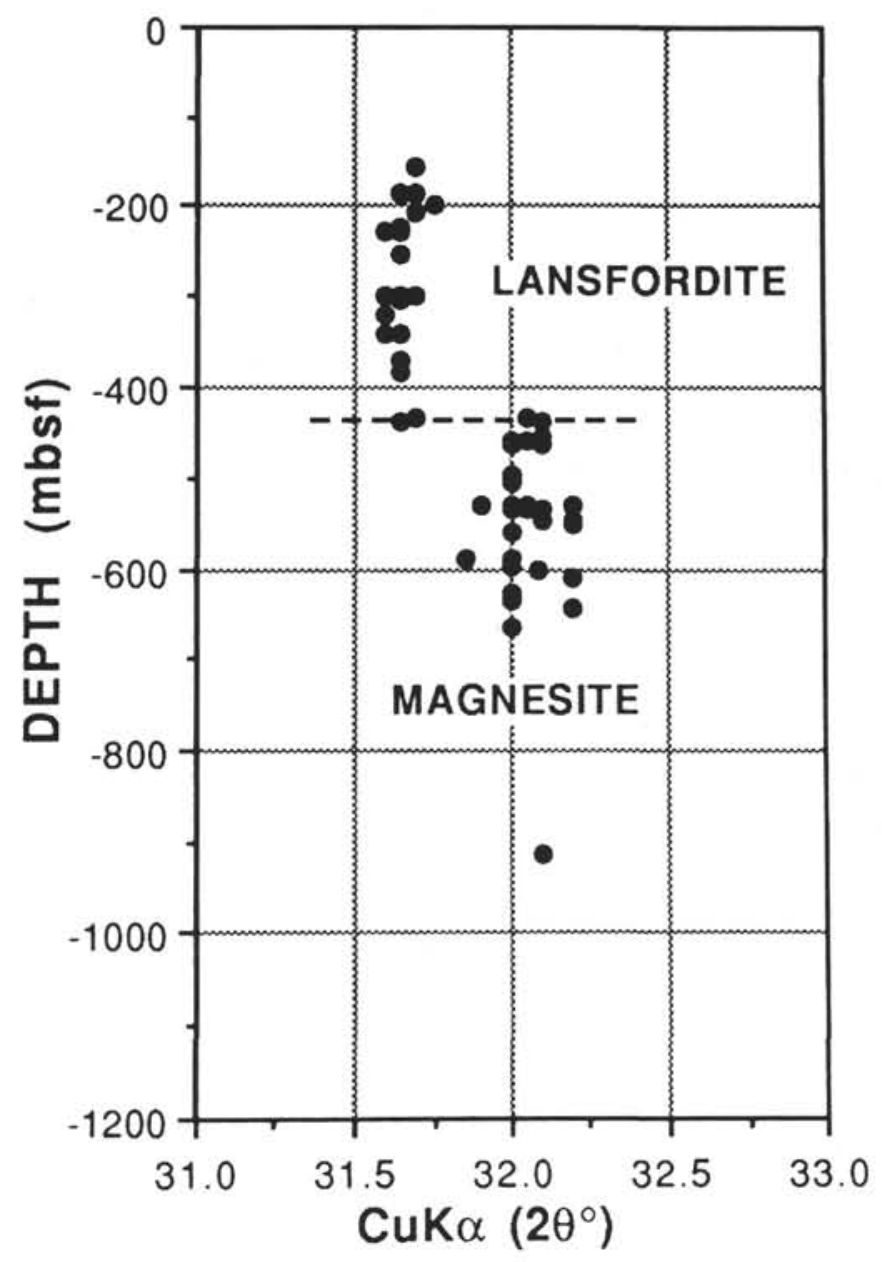

Figure 7. Variations in $2 \theta^{\circ}(\mathrm{CuK} \alpha)$ values of lansfordite and magnesite plotted against the depth.

\section{Textural Relations and Petrography}

\section{Rhodochrosite}

Viewed with SEM, rhodochrosite occurs as lighter, structureless, microspherules $2-12 \mu \mathrm{m}$ in diameter, filling interstices of the clay matrix and biosiliceous components. Bright spots less than a few micrometers in diameter, presumably iron and manganese(?) oxides or sulfides, and darker nuclei 3 to $5 \mu \mathrm{m}$ across occur sporadically in the larger rhodochrosite spherules (Pl. 1, Fig. 1). Darker nuclei are considered to be Ca-phosphate based on semiquantitative EDS analyses. Microspherules typically coalesce to form larger aggregates up to $90 \mu \mathrm{m}$ in diameter. Plate 1, Figure 2, illustrates a composite spherule that has grown over a foraminifer test.

\section{Magnesite}

Magnesite is recognized with SEM as lighter, rhombohedral grains with sharp edges and corners in a clay matrix (PI. 1, Figs. 3 and 4). The crystal grains range in size from 2 to $15 \mu \mathrm{m}$ along the longest axis but are mostly about $10 \mu \mathrm{m}$; distinct structures such as light and dark banding and inclusions were not visible under SEM. In some cases, magnesite rhombohedrons grow on or partly enclose rhodochrosite spherules (Pl. 1, Figs. 5 and 6), indicating that the magnesite precipitation must have occurred after the precipitation of the rhodochrosite.
SEM observation of a lansfordite(?) crystal did not reveal any distinctive crystal morphology but showed irregularly shaped, dark, cloudy patches and flocculent of about $5-20 \mu \mathrm{m}$ in diameter.

\section{Dolomite}

Dolomite crystals display wide variations in crystal habit and size, reflecting a variable degree of recrystallization with depth. Based on the degree of recrystallization of dolomite, dolomite rocks have been classified into three categories: no to poor recrystallization (type A), moderate recrystallization (type B), and intensive recrystallization (type $\mathrm{C}$ ). Plate 2 shows typical textures of type $\mathrm{A}$, $\mathrm{B}$, and $\mathrm{C}$ dolomites.

Type A dolomites (Pl. 2, Figs. 1 and 2) consist of fine to cryptocrystalline dolomite, characterized by well-preserved diatom frustules and sponge spicules; cavities of foraminifer tests are filled by a fine- to coarse-grained mosaic of dolomite crystals. Type B dolomites (Pl. 2, Figs. 3) are made up of anhedral to subhedral crystals $3-50 \mu \mathrm{m}$ in diameter; diatom frustules and sponge spicules are either dissolved or replaced by dolomite, but remnants and ghost images are still visible. Type $\mathrm{C}$ dolomites ( $\mathrm{Pl}$. 2 , Figs. 4) are characterized by coarsely recrystallized grains of dolomite, ranging between 30 and $450 \mu \mathrm{m}$ in diameter. Diatoms and sponges were not recognized, and sedimentary structures such as thin laminae and burrows have been obliterated.

The degree of recrystallization of dolomite is not a simple function of burial depth. Type A ranges in depth between 247 and 897 mbsf, type B between 466 and 934 mbsf, and type C between 466 and 1040 mbsf. A 35-cm-thick dolomite layer, in Section 128-799A-51X-CC, at 465 mbsf exhibits gradations in the degree of recrystallization from type A and B in the center of the layer (subsamples 7 and 10) to type $\mathrm{C}$ at the upper margin (subsample 2).

\section{Chemical Compositions}

Spot analysis of $\mathrm{Ca}, \mathrm{Mg}, \mathrm{Mn}$, and $\mathrm{Fe}$ concentrations in the carbonate phases using the SEM-EDS system were made on 18 carbonate rock samples from Hole 799A and 32 samples from Hole 799B. The total number of spots is equivalent to 349 points. The results have been recalculated as molar percentages and are represented on a ternary plot diagram with apexes of $\mathrm{CaCO}_{3}, \mathrm{MgCO}_{3}$, and $\mathrm{MnCO}_{3}+\mathrm{FeCO}_{3}$ (Fig. 9). Variations of cation compositions for the various diagenetic carbonates are shown in Figure 10 as a function of the depth below seafloor. Generally important features of the chemical composition of the Site 799 carbonates are (1) wide variations in chemical compositions, (2) high Mn concentrations, and (3) the absence of siderite.

\section{Calcite}

Calcite composition was determined for only one calcitic sample, 128-799B-2R-CC (459.66 mbsf), because the discrimination of minute anhedral crystals of diagenetic calcite from biogenic and other diagenetic carbonates was not easily accomplished. This sample contains a ferroan calcite, which is relatively pure compared with the other diagenetic carbonates. $\mathrm{CaCO}_{3}$ ranges between 95.1 and $98.7 \mathrm{~mol} \%$, whereas $\mathrm{Mg}, \mathrm{Mn}$, and Fe contents are less than 1.8, 0.2, and $3.1 \mathrm{~mol} \%$, respectively.

\section{Rhodochrosite}

The rhodochrosite from Site 799 is highly calcian, containing approximately 22.5 to $38.5 \mathrm{~mol} \% \mathrm{CaCO}_{3}$. In contrast, $\mathrm{Mg}$ and $\mathrm{Fe}$ contents are relatively low, mostly below 10 and $3 \mathrm{~mol} \%$, respectively. Thus, the variation in the chemical composition is primarily con- 
Relative Peak Intensites LANSFORDITE

MAGNESITE
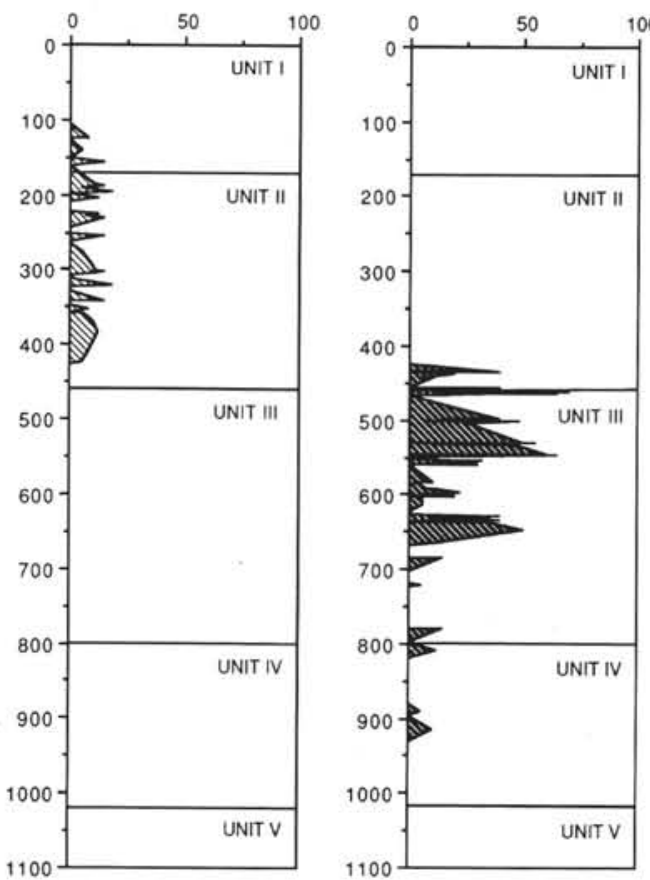

DOLOMITE

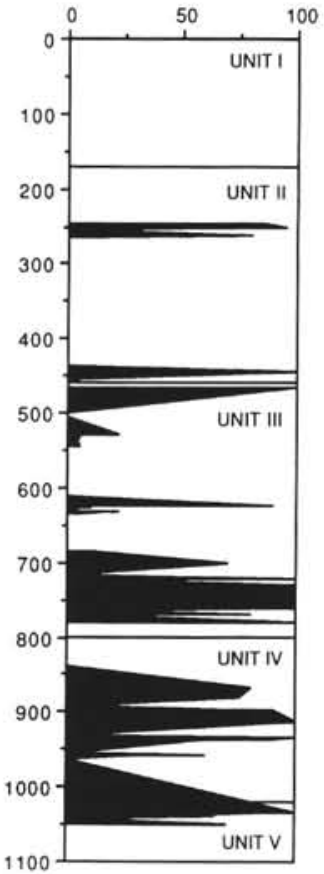

CALCITE
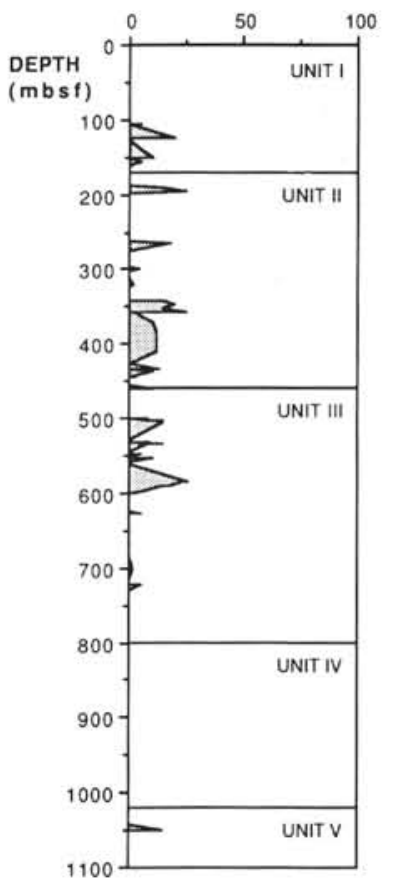

RHODOCHROSITE

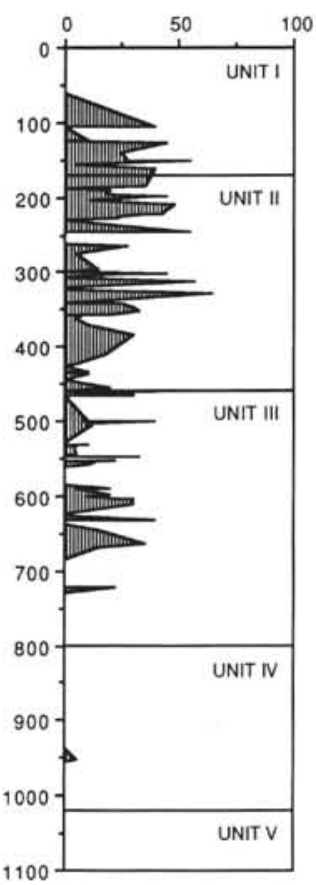

Figure 8. Abundance and distribution of diagenetic carbonates at Site 799, represented by X-ray peak intensities. Note the apparently depth-controlled pattern.

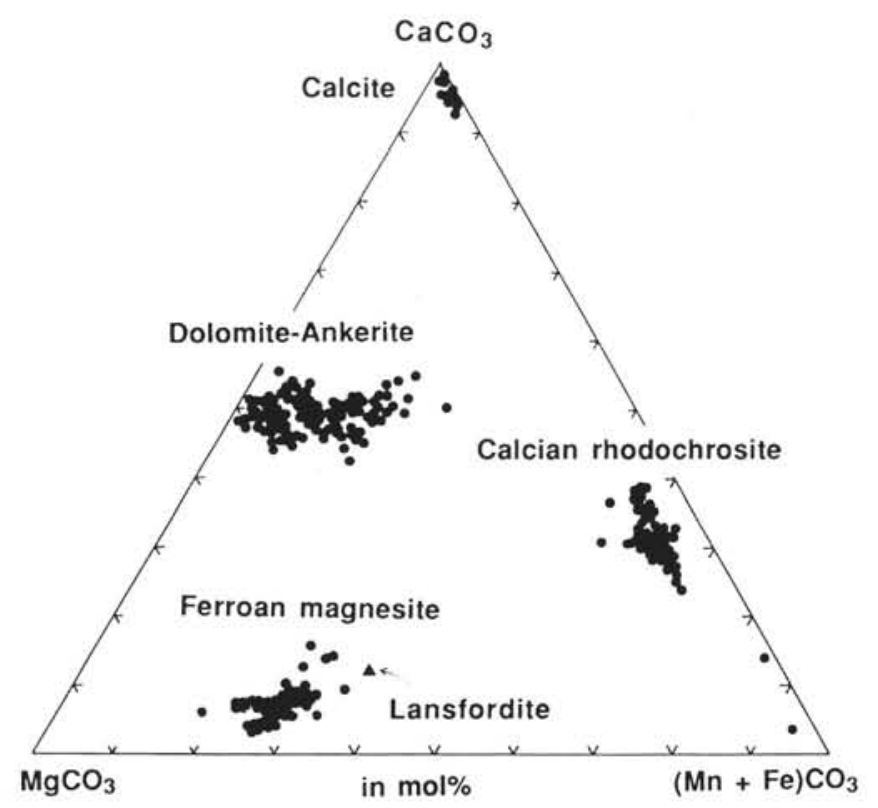

Figure 9. Chemical compositions of diagenetic carbonates at Site 799, represented by molar percentage. Approximate composition of lansfordite is given by a solid triangle.

trolled by the degree of Mn-substitution by $\mathrm{Ca}$. In spite of wide variations in $\mathrm{Mn}$ content of rhodochrosite within single layers and nodules, a systematic compositional gradient has not been recognized.

\section{Magnesite}

The magnesite contains significant amounts of $\mathrm{Ca}, \mathrm{Fe}$, and $\mathrm{Mn}$ and is actually breunnerite. The maximum concentration of $\mathrm{Mg}$ is only about $76.0 \mathrm{~mol} \%$. Ca content varies between approximately 5.0 and $14.5 \mathrm{~mol} \%$, whereas $\mathrm{Fe}$ and $\mathrm{Mn}$ show wide variations ranging from 1.5 to $25.5 \mathrm{~mol} \%$, and from 3.5 to $20.5 \mathrm{~mol} \%$, respectively. Except in a few analyses, the $\mathrm{Fe}$ content is greater than the Mn content, but the difference is usually only a few mol\%. The total Fe and $\mathrm{Mn}$, however, shows narrower range between 17.5 and $33.5 \mathrm{~mol} \%$, suggesting that $\mathrm{Fe}$ and $\mathrm{Mn}$ substitute for each other to some extent.

\section{Lansfordite}

Chemical analysis of lansfordite was not successful because of its instability with electron bombardment. Semiquantitative analyses, however, revealed that $100 \%$-normalized values of $\mathrm{Ca}, \mathrm{Mg}$, and $\mathrm{Fe}+$ Mn are $10 \pm 5,56 \pm 5$, and $34 \pm 5 \mathrm{~mol} \%$, respectively, similar to that of magnesite.

\section{Dolomite}

Site 799 dolomite ranges from nearly stoichiometric dolomite to ankerite with an anomalously high Mn content, reaching up to $20 \mathrm{~mol} \%$; the Fe content varies between 0 and $12 \mathrm{~mol} \%$ but is mostly less than $8 \mathrm{~mol} \%$. The Mn content of the dolomites, particularly for samples with a lower $\mathrm{Mn}+\mathrm{Fe}$ and higher $\mathrm{Mg}$ contents, is greater than the $\mathrm{Fe}$ content, whereas for samples with an ankerite composition, Fe dominates over $\mathrm{Mn}$. This implies that the molar ratio of $\mathrm{Mn} /(\mathrm{Mn}+\mathrm{Fe})$ in dolomite decreases with the $\mathrm{Mg}$ content.

The dolomite layer at $247 \mathrm{mbsf}$ is composed of nearly stoichiometric dolomite with approximately $51 \mathrm{~mol}^{2} \mathrm{CaCO}_{3}$ and 1 to $2.5 \mathrm{~mol} \%$ $(\mathrm{Mn}+\mathrm{Fe}) \mathrm{CO}_{3}$. Dolomites recovered from below $440 \mathrm{mbsf}$ have a wide compositional range and do not vary systematically with depth.

$\mathrm{Fe}$ and $\mathrm{Mn}$ contents tend to increase away from the centers of dolomite layers, as revealed by subsample analyses. The Fe and $\mathrm{Mn}$ contents in a 21-cm-thick layer, from Sample 128-799B-48R-2, 74$95 \mathrm{~cm}$, at $897 \mathrm{mbsf}$, increase from 3 to $15 \mathrm{~mol} \%(\mathrm{Fe}+\mathrm{Mn}) \mathrm{CO}_{3}$ in the center to 6 to $26 \mathrm{~mol} \%$ at the rim. Likewise, in a 10-cm-thick bed in Sample 128-799B-54R-CC, 0-10 cm, at $956 \mathrm{mbsf}$, the content in- 
creases outward from $2.0-3.5 \mathrm{~mol} \%$ to $2.5-9.0 \mathrm{~mol} \%$. The observed compositional gradients strongly suggest that "lateformed dolomite" (i.e., occurring near the edges of the layers) is more enriched in iron and manganese than "early-formed dolomite."

\section{Isotopic Compositions}

Stable carbon and oxygen isotope compositions were determined for 12 calcite samples collected at depths from 123 to $1049 \mathrm{mbsf}, 27$ rhodochrosite samples from 105 to $665 \mathrm{mbsf}, 2$ lansfordite samples from 229 and 301 mbsf, 24 magnesite samples from 460 to 809 mbsf, and 47 dolomite samples from 247 to 1050 mbsf. The results are presented in Table 1 and Figure 11 , where the $\delta^{13} \mathrm{C}$ and $\delta^{18} \mathrm{O}$ values are plotted against depth. Figure 12 is a cross-plot of the $\delta^{13} \mathrm{C}$ and $\delta^{18} \mathrm{Ov}$ values for the samples. The values range from -24.3 to $5.2 \%$ oo for $\delta^{13} \mathrm{C}$ and from -9.7 to 5.6 $\%$ for $\delta^{18} \mathrm{O}$. Different 'carbonate minerals appear to cluster in the different area in the diagram.

\section{Carbon Isotope Composition}

The carbon isotope composition of calcite apparently increases with depth from $-24.3 \%$ oo to $-11 \%$ o. The most negative value was encountered in a small, indurated, rhodochrosite-calcite nodule, $2.5 \mathrm{~cm}$ in diameter, in Sample 128-799A-30X-3, 102-108 cm, at $264.52 \mathrm{mbsf}$. A similar $\delta^{13} \mathrm{C}$ vs. depth profile was recognized for the rhodochrosite, although the values ( -14.8 to $1.4 \mathrm{o} \%$ ) show more scatter. In contrast, depth gradients were not recognized for magnesite and dolomite. Magnesite values are scattered within a narrower range of values between -7.5 and $5.1 \%$, whereas dolomite ranges widely from -23.7 to $2.9 \%$ o. The $\delta^{13} \mathrm{C}$ values of lansfordite $(-2.1$ and $-1.6 \%$ oo are included within the range of magnesite.

The shallowest dolomite layer, $8 \mathrm{~cm}$ thick, in a Section 128-799A$28 \mathrm{X}-1,4-12 \mathrm{~cm}$ (247 mbsf; Unit II) is extremely depleted in 13C, with $\delta^{13} \mathrm{C}$ values between $-23.7 \% \mathrm{o}$ and $-20.0 \%$. The dolomites at about $450 \mathrm{mbsf}$ around the boundary between Unit II and Unit III are comparatively enriched in $13 \mathrm{C}$ with $\delta^{13} \mathrm{C}$ values between -3.4 and $2.9 \%$. From about 700 to $1000 \mathrm{mbsf}$ (Units III and IV) the values are again significantly depleted $(-4.2$ to $-15.9 \%$ oo (Fig. 11). The $\delta^{13} \mathrm{C}$ values of dolomite taken from the same stratigraphic layer can vary up to $10 \%$. This indicates that depth was not the primary factor controlling the $\delta^{13} \mathrm{C}$ values of dolomite, but changing environmental conditions and recrystallization are more significant.

\section{Oxygen Isotope Composition}

Magnitude of variations in the $\delta^{18} \mathrm{O}$ values of Site 799 carbonates is relatively small compared with that of the $\delta^{13} \mathrm{C}$ values. In particular, rhodochrosite varies $\pm 1.5 \mathrm{o} \%$ at about $4 \%$ oo. Rhodochrosite at shallower depths above $350 \mathrm{mbsf}$ is slightly more enriched in ${ }^{18} \mathrm{O}$ than the deeper rhodochrosite. Calcite in the depth range of 100 to $600 \mathrm{mbsf}$ exhibits similar $\delta^{18} \mathrm{O}$ values to those of rhodochrosite, ranging between 1.2 and $4.0 \%$ o; furthermore, the deeper calcites are more depleted than the shallower ones, as in the case of rhodochrosite (Fig. 11). Calcite cements in sandstone at 1049 mbsf have exceptionally negative $\delta^{18} \mathrm{O}$ values $(-11.4$ and $-8.0 \%$ oo).

The two samples of lansfordite from different layers have an almost constant $\delta^{18} \mathrm{O}$ value, about $5 \%$ oo. The $\delta^{18} \mathrm{O}$ values of magnesite, ranging between $-5.2 \%$ and $0.6 \%$, are quite different from those of lansfordite.

The shallowest dolomite layer has $\delta^{18} \mathrm{O}$ values of $3.4-5.4 \%$ o, which are about $5-15 \%$ heavier than those of the deeper dolomites with values of -10 to $-0.5 \%$. No relationship between $\delta^{18} \mathrm{O}$ values and the depth of occurrence apparently exists for either dolomite and magnesite. Compositional zoning within a single dolomite layer is, however, evident as seen in Figure 13. The $\delta^{18} \mathrm{O}$ values of dolomite in the center of the layer (Sample 128-799B-48R-2, 76-95 cm, $897 \mathrm{mbsf}$ ) are about -1.5 to $-2.1 \%$, whereas the value decreases to $-8.3 \%$ at the margin. This indicates that the later dolomites are more depleted in ${ }^{18} \mathrm{O}$ compared with early dolomite, probably reflecting an increase in formation temperatures with depth.

\section{Compositional Zoning}

Gradients in isotope compositions from the center to the edge of single carbonate beds and nodules have been examined for one rhodochrosite nodule, four magnesite layers, and eight dolomite layers.

A solid rhodochrosite nodule $2.0 \times 1.5 \mathrm{~cm}$ (Sample 128-799A$22 \mathrm{X}-3,50-53 \mathrm{~cm}$ ) is composed of two distinct color zones, with a dark-colored core and a 3- to 5-mm thick, olive yellow rind. Carbon and oxygen isotope compositions are, however, within the range of $-7.54 \%$ and $-8.24 \%$, and 4.86 and 4.51 , respectively. The chemical formula for the samples can be approximately represented by $\mathrm{Mg}_{0.08} \mathrm{Ca}_{0.30}(\mathrm{Fe}+\mathrm{Mn})_{0.61} \mathrm{CO}_{3}$, with $1 \mathrm{~mol} \%$ deviations. Measurements of the $\mathrm{d}(104)$ spacing have also revealed that rhodochrosite layers and nodules do not have distinctive compositional zoning. Variations in the $\delta^{13} \mathrm{C}$ and $\delta^{18} \mathrm{O}$ values of magnesite within a single layer are also small, ranging from 0.2 to $1.5 \%$ and from 0.4 to $0.8 \%$ oo, respectively, and a general trend from center to rim has not been recognized.

Contrasting with the rhodochrosite and magnesite, dolomite-ankerite beds exhibit significant isotopic and chemical gradients, as illustrated in Figure 13. The best example is a 35 -cm-thick dolomite layer in a Section 128-799A-51X-CC, 0-35 cm at $465.9 \mathrm{mbsf}$; the upper (outer) portion of this layer has the $\delta^{13} \mathrm{C}$ value of $-1.09 \mathrm{o} / \mathrm{oo}$ and $\delta^{18} \mathrm{O}$ value of $-6.85 \%$, with values increasing inward to 2.88 and -5.20 $\%$, respectively, at about $27 \mathrm{~cm}$ from the top surface, and again decreasing to 1.27 and $-5.90 \%$, respectively at the base of the layer. As the lower part of this layer was probably broken during drilling, the "real base" of this layer may be more depleted in ${ }^{13} \mathrm{C}$ and ${ }^{18} \mathrm{O}$. On the other hand, the content of $\mathrm{Fe}+\mathrm{Mn}$ tends to increase from about $4 \mathrm{~mol} \%$ in the center to $6.5 \mathrm{~mol} \%$ in the upper portion. The gradient in the $\delta^{18} \mathrm{O}$ values is greater in another dolomite layer (Sample 128-799B-48R-2, $87-95 \mathrm{~cm}, 897 \mathrm{mbsf}$ ) in which the values are between -1.5 and -8.26 $\%$. Carbon isotope compositions, however, increase outward from -12.83 to $-7.45 \%$ oo.

Figure 13 also depicts the relationship between oxygen isotope composition and the degree of recrystallization of dolomite as determined under the microscope. Dolomites having the $\delta^{18} \mathrm{O}$ values greater than approximately $-2 \%$ are generally classified as type A, none- to poorly recrystallized, whereas isotopically lighter dolomites have been moderately (type B) to intensively (type C) recrystallized. It is evident from Figure 13 that the dolomites from the outer rim of the beds are more depleted in ${ }^{18} \mathrm{O}$ and probably more recrystallized.

\section{DISCUSSION}

\section{Depth of Diagenetic Carbonate Formation}

The oxygen isotope composition of carbonates is primarily controlled by (1) $\delta^{18} \mathrm{O}$ values of the water from which the carbonates precipitated and (2) temperature of precipitation. For calcite, the oxygen isotope composition $(\delta c)$ is expressed by $\delta^{18} \mathrm{O}$ values of the water $(\delta \mathrm{w})$ and temperature of formation (T, Kelvin) as (O’Neil et al., 1969);

$$
\delta c-\delta w=10^{3} \ln \alpha_{\text {calcite-water }}=2.78\left(10^{6} T^{-2}\right)-2.89
$$

If the temperature and $\delta^{18} \mathrm{O}$ of water are known, we can calculate the $\delta^{18} \mathrm{O}$ values of calcite that precipitated in equilibrium with these conditions. For the other carbonates, the equilibrium values of $\delta^{18} \mathrm{O}$ can also be obtained using $\delta \mathrm{c}$ values and the fractionation factors for mineral pairs dolomite-calcite, rhodochrosite-calcite, and magnesite-calcite. For dolomite, a $10^{3} \ln \alpha_{\text {dol-cal }}$ value of 3.4 has been applied in this study, according to the values reported by Tarutani et al. (1969), Shepard and Schwarz (1970), and Fritz and Smith (1970). For rhodochrosite and magnesite, 
A

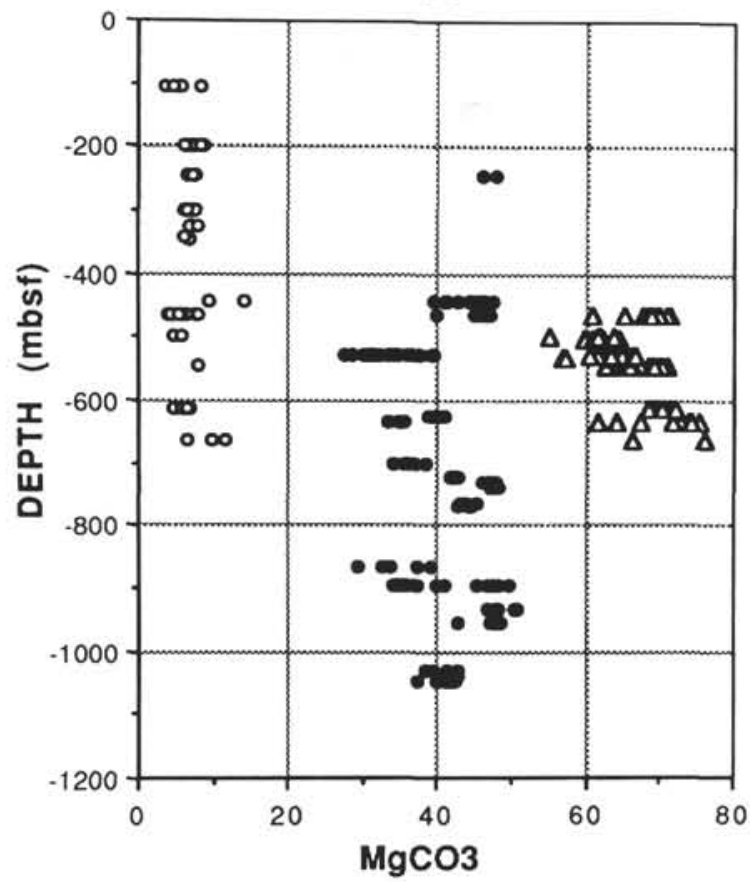

C

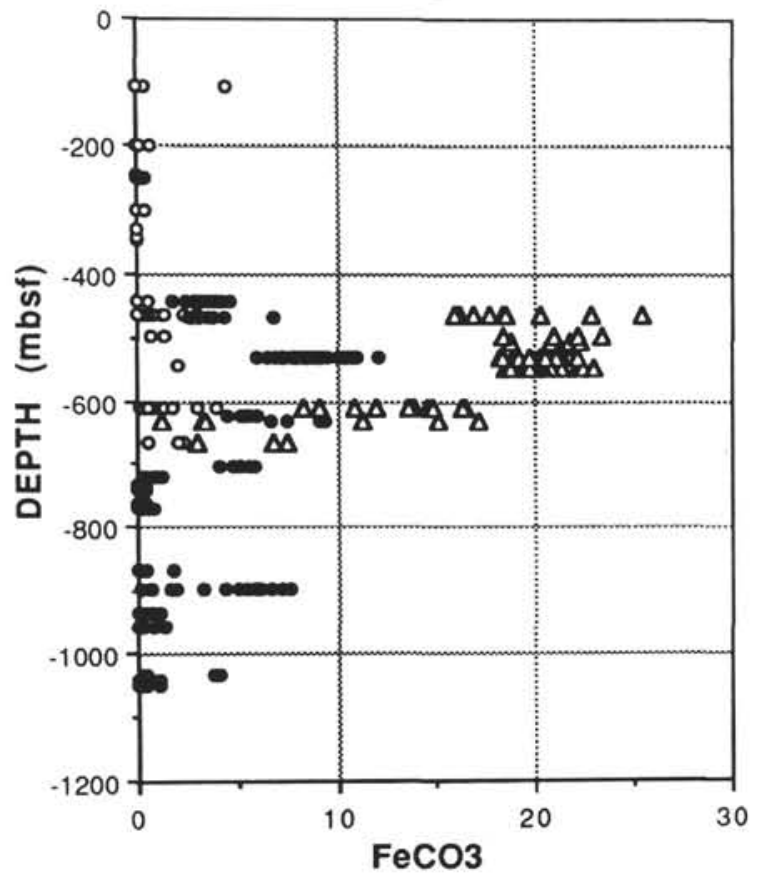

B

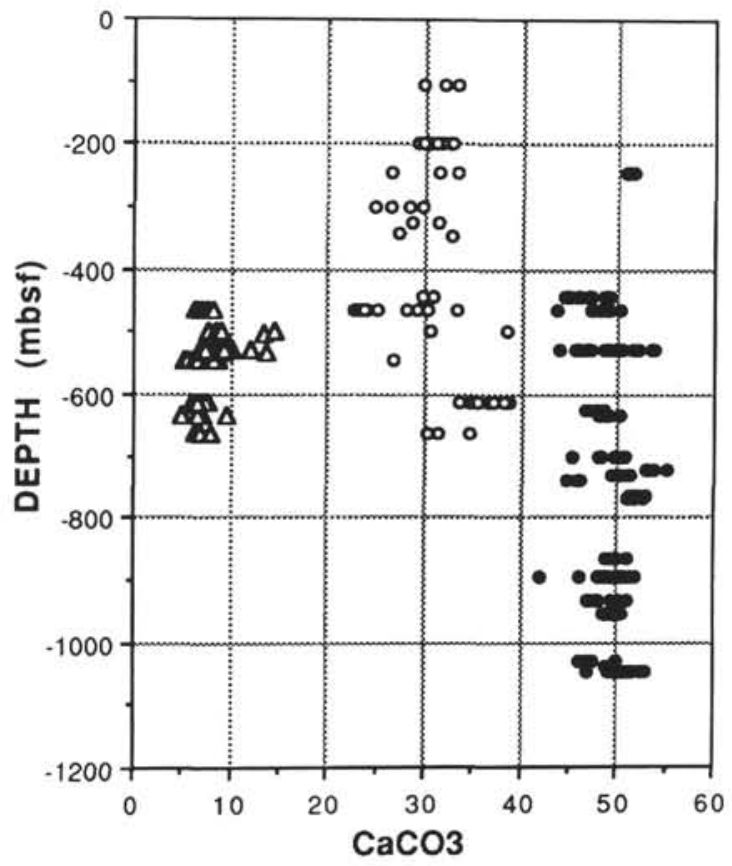

D

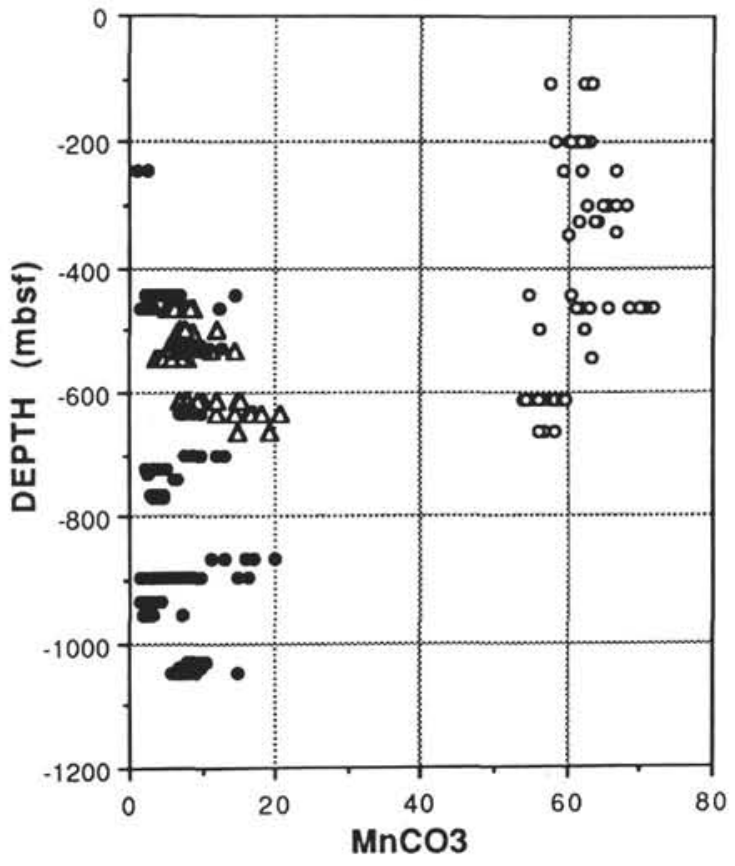

Figure 10. Variation in chemical compositions (mol\%) in diagenetic carbonates with depth. A. Mg concentrations. B. Ca concentration. C. Fe concentration. D. Mn concentration. E. Fe + Mn concentration.

fractionation constants of $10^{3} \ln \alpha_{\text {rhod-cal }}=-0.4$ and $10^{3} \operatorname{In} \alpha_{\text {mag-cal }}=6.4$ have been estimated from the values for $10^{3} \mathrm{In} \alpha_{\mathrm{CaCO}_{-}-\mathrm{H}_{2} \mathrm{O}}(28.0)$, $10^{3} \operatorname{In} \alpha_{\mathrm{SrCO}_{3}-\mathrm{H}_{2} \mathrm{O}}(26.8), 10^{3} \mathrm{In} \alpha_{\mathrm{CaCO}_{3}-\mathrm{H}_{2} \mathrm{O}}(26.1)$, and $10^{3} \mathrm{In}_{\mathrm{BaCO}_{3}-\mathrm{H}_{2} \mathrm{O}}$ (24.5) based on the assumption that the fractionation constants of divalent metal carbonates $\left(10^{3} \mathrm{In}_{\mathrm{MCO}_{3}-\mathrm{H}_{2} \mathrm{O}}\right)$ increase with decreasing atomic weight of divalent cations (mass, $\mathrm{M}^{2+}$ ) (O'Neil, 1977).
Oxygen isotope compositions of the interstitial waters at Site 799 for the depth interval from 16.55 to 435.6 mbsf (Matsumoto, this volume) reveal rather systematic decrease with depth at a virtually constant rate of $-0.91 \% \% / 100 \mathrm{~m}$. The $\delta^{18} \mathrm{O}$ values of the interstitial waters $(\delta w)$ can be approximately expressed by $\delta w=-0.20-0.0091 \mathrm{D}$, Where $D$ is the depth in meters from the seafloor. Temperature 


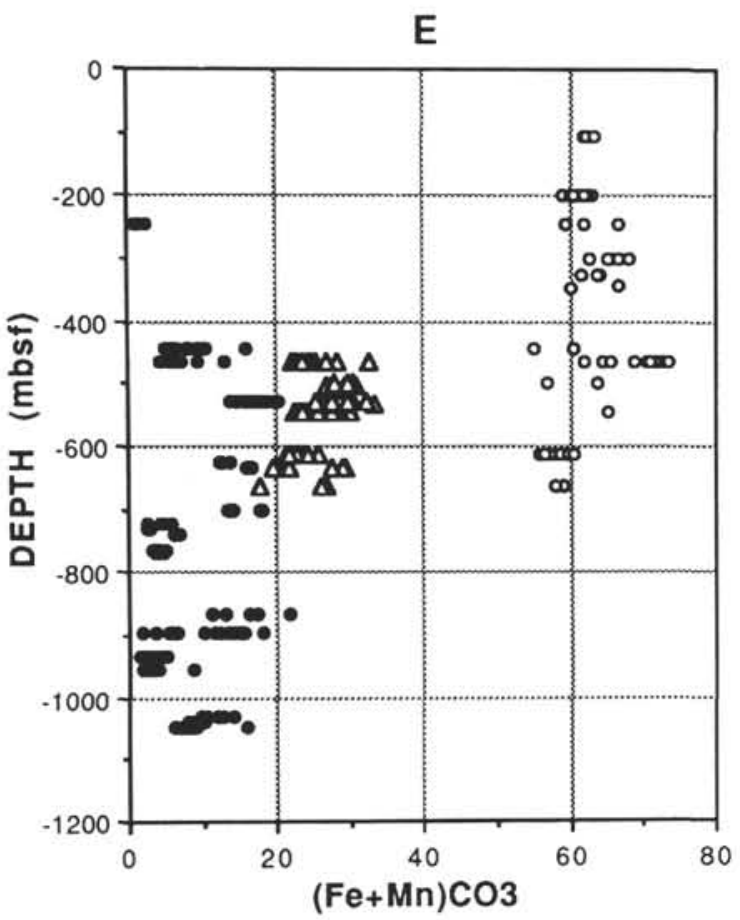

\section{- Rhodochrosite \\ $\Delta$ Magnesite \\ - Dolomite}

Figure 10 (continued).

measurements with a temperature-probe for the interval between 39.5 and 174.5 mbsf (Shipboard Scientific Party, 1990a, f, g) allowed calculation of the overall gradient in temperature as $98^{\circ} \mathrm{C} / \mathrm{km}$. This value may change with depth, reflecting the variation of thermal conductivity. However, as the conductivity values range mostly between 0.8 and $1.2 \mathrm{~W} / \mathrm{m} \cdot \mathrm{K}$ down to the depth of $600 \mathrm{mbsf}$ (Shipboard Scientific Party, 1990a, f, g), the depth-temperature relation can be approximated as $t=0.098 D$, where $t$ is temperature in ${ }^{\circ} \mathrm{C}$ and $D$ is depth in meters, at least for the upper $600 \mathrm{~m}$. Substituting $(0.098 D+273.15)$ for $T$ (Kelvin) and $(-0.2-0.009 D)$ for $\delta w(\mathrm{o} / \mathrm{oo})$ in equation (1), the equilibrium $\delta^{18} \mathrm{O}$ values of calcite $(\delta \mathrm{c})$ are equated to the depth $(D$, in meters) at which the calcite was precipitated, as:

$$
\begin{aligned}
\delta c= & 2.78(106(0.098 D+273.15)-2) \\
& -2.89+(-0.2-0.0091 D) .
\end{aligned}
$$

For dolomite $(\delta \mathrm{d})$, rhodochrosite $(\delta \mathrm{r})$, and magnesite $(\delta \mathrm{m})$, the equilibrium values of $\delta^{18} \mathrm{O}$ are $\delta \mathrm{d}=\delta c-3.0, \delta r=\delta c+0.4$, an $\delta \delta m=\delta \mathrm{c}-$ 6.4 , respectively, using the above fractionation constants. The equilibrium $\delta^{18} \mathrm{O}$ values for lansfordite are not given because the fractionation factors are not well known.

No data on the paleogeothermal gradient at Site 799 is available, but, considering that one of the spreading centers existed in the Kita-Yamato Trough, the heat flow is expected to have been much higher in the past than at present. The highest recorded geothermal gradient in the Japan Sea during Legs 127 and 128 was approximately $180^{\circ} \mathrm{C} / \mathrm{km}$ (Shipboard Scientific Party, 1990b, c, d, e). If we substitute this gradient, $t=0.18 \mathrm{D}$, in equation (1), the equilibrium $\delta^{18} \mathrm{O}$ value of carbonates decrease more rapidly with depth, e.g., about $-20 \%$ o for calcite at 500 mbsf. Furthermore, the $\delta^{18} \mathrm{O}$ values of the interstitial waters are explained to have been controlled primarily by the altera- tion of Layer 2 basalt (negative shift) and silica diagenesis (positive shift) (Matsumoto, this volume). With greater effect from basalt alteration and smaller contribution from the silica diagenesis in the past, a more rapid decrease in $\delta^{18} \mathrm{O}$ of the interstitial waters is expected. Coupled with the possible higher geothermal gradients, the equilibrium $\delta^{18} \mathrm{O}$ of diagenetic carbonates would decrease more rapidly with depth than the gradients calculated from the present depth profiles of the temperature and the $\delta^{18} \mathrm{O}$ water values. Therefore, the equilibrium $\delta^{18} \mathrm{O}$ values given by equation (2) are considered to be the maximum values.

The solid lines in Figure 14 depict the calculated variation in the equilibrium $\delta^{18} \mathrm{O}$ values of various carbonates with depth. Rhodochrosite, calcite, dolomite, and magnesite precipitated at $0 \mathrm{mbsf}$ are expected to have $\delta^{18} \mathrm{O}$ values of $3.9,4.3,7.3$, and $10.7 \%$, respectively. Carbonates formed at deeper levels become more depleted in ${ }^{18} \mathrm{O}$ at an approximate rate of $-3.7 \mathrm{o} / 100 \mathrm{~m}$, reflecting the higher temperatures and decreasing $\delta^{18} \mathrm{O}$ values of the interstitial waters. Hence, in turn, the dolomite with $\delta^{18} \mathrm{O}$ of $-5 \%$ is estimated to 2 have formed at about $420 \mathrm{mbsf}$. However, as discussed above, the equilibrium $\delta^{18} \mathrm{O}$ values may have decreased more rapidly with depth and the true depth of precipitation may have been as much as $100-150 \mathrm{~m}$ shallower than the estimated depths.

Figure 14 also indicates the measured $\delta^{18} \mathrm{O}$ values of the diagenetic carbonates plotted against the depth at which they were recovered. The striking feature is that almost all of the measured data occupy the area below the respective lines. This indicates that almost all of the Site 799 carbonates are not in oxygen isotopic equilibrium with the ambient waters. Most likely, they were not precipitated at their present depth of occurrence, but more likely formed in the past at shallower depths and lower temperatures.

Assuming that the geothermal gradient and the depth profile of $\delta^{18} \mathrm{O}$ of the interstitial waters at Site 799 did not change greatly throughout the early Miocene to Quaternary, dolomites with $\delta^{18} \mathrm{O}$ values between -9.73 and $5.37 \%$ are estimated to have formed in the depth interval of approximately $60-580 \mathrm{mbsf}$ based on the relationship between the depth and the equilibrium $\delta{ }^{18} \mathrm{O}$ values in Figure 14. Magnesite formed from 310 to $510 \mathrm{mbsf}$, and calcite was probably precipitated predominantly within the depth interval from 0 to $84 \mathrm{mbsf}$, but the calcite cementation of sandstone in the lowermost part of Unit IV is estimated to have occurred at 400-510 mbsf (Fig. 15). Rhodochrosite, ranging in $\delta^{18} \mathrm{O}$ values from 2.37 to 5.70 $\%$, probably formed at very shallow burial depths $(<32 \mathrm{~m})$. The heaviest estimated $\delta^{18} \mathrm{O}$ value of rhodochrosite is about $4 \%$, but rhodochrosites in the Pliocene sediments have $\delta^{18} \mathrm{O}$ values greater than $4 \%$ oo (Fig. 15). This disparity may indicate (1) that $\delta^{18} \mathrm{O}$ of the earlier bottom water was isotopically heavier by a few parts per mil than at present; or has been caused by the (2) Ca substitution in rhodochrosite, or, more likely, (3) the uncertainty of the fractionation factor between rhodochrosite and water.

Estimates of the formation depth indicate that the diagenetic carbonates at Site 799 formed primarily within the depth range of 0 to a maximum of $600 \mathrm{mbsf}$. They also imply that rhodochrosite and most of the calcite were precipitated at shallow depths prior to precipitation of dolomite and magnesite. The succession is quite consistent with the order of precipitation determined from the textural relations observed between rhodochrosite and magnesite, and between rhodochrosite and dolomite.

\section{Carbon Isotope Signatures and Diagenetic Stages}

In Figure 16 , the $\delta^{13} \mathrm{C}$ values of the diagenetic carbonates are plotted against the estimated depth of formation. Rhodochrosite, which formed near the sediment-water interface, has $\delta^{13} \mathrm{C}$ values between -4 and $-15 \%$, and calcites, which formed between 0 and $80 \mathrm{mbsf}$, are more depleted in ${ }^{13} \mathrm{C}$, with $\delta^{13} \mathrm{C}$ value of approximately -13 to $-25 \%$. The $13 \mathrm{C}$ values of the dolomite tend to increase with depth of formation, from $-25 \mathrm{o} \%$ at about $50 \mathrm{mbsf}$ to approximately 0 to $-10 \%$ at about $450 \mathrm{mbsf}$. Deeply formed calcites are included 
Table 1. Carbonate mineralogy of Site 799 sediments and the carbon and oxygen isotope compositions (o/oo vs. PDB) of various diagenetic carbonates and their estimated depths of precipitation of calcite, rhodochrosite, magnesite, and dolomite.

\begin{tabular}{|c|c|c|c|c|c|c|c|c|c|c|c|c|c|c|c|c|c|c|c|c|}
\hline \multirow[b]{2}{*}{$\begin{array}{l}\text { Leg-Hole-Core-Section, } \\
\text { interval (cm) }\end{array}$} & \multirow{2}{*}{$\begin{array}{l}\text { Depth } \\
\text { (mbs) }\end{array}$} & \multicolumn{5}{|c|}{ XRD Peak Intensities } & \multicolumn{2}{|c|}{ Calcite } & \multirow[b]{2}{*}{ Depth-1 } & \multirow{2}{*}{\multicolumn{2}{|c|}{$\begin{array}{l}\text { Rhodochrosite } \\
\delta^{13} \mathrm{C}\left(\alpha_{0 \infty}\right) \quad \delta^{110} \mathrm{O}\left(\alpha_{00}\right)\end{array}$}} & \multirow[b]{2}{*}{ Depth-2 } & \multirow{2}{*}{\multicolumn{2}{|c|}{ Lansfordite }} & \multirow{2}{*}{\multicolumn{2}{|c|}{ Magnesite }} & \multirow[b]{2}{*}{ Depth-3 } & \multirow{2}{*}{\multicolumn{2}{|c|}{$\begin{array}{l}\text { Dolomite } \\
\delta^{13} \mathrm{C}\left(\alpha_{\infty}\right) \\
\delta^{18} \mathrm{O}\left(\alpha_{\infty}\right)\end{array}$}} & \multirow[b]{2}{*}{ Depth-4 } \\
\hline & & Calcite & Rhodochrosite & Lansfordite & Magnesite & Dolomite & $8^{13} \mathrm{C}\left(\alpha_{\infty} / \infty\right)$ & $\delta^{1 / 8} \mathrm{O}\left(\alpha_{000}\right)$ & & & & & & & & & & & & \\
\hline $128-799 \AA-12 \mathrm{H}-6,54-56$ & 105.24 & 5 & 40 & 0 & 0 & 0 & & & & -8.74 & 5.36 & 0 & & & & & & & & \\
\hline $\begin{array}{l}128-799 \mathrm{~A}-12 \mathrm{12}-\mathrm{CC}, 11-13-13 \\
112899 \mathrm{-1}-1 \mathrm{H}-5,64-66\end{array}$ & $\begin{array}{l}106.70 \\
123.14\end{array}$ & 0 & 28 & 0 & 0 & ${ }_{0}^{0}$ & & & & -8.64 & 5.70 & 0 & & & & & & & & \\
\hline $\begin{array}{l}128-799 \mathrm{~A}-1-14-5-5,64-66 \\
128-799 A-15 H-1,97-99\end{array}$ & $\begin{array}{l}123.14 \\
127.07\end{array}$ & $\begin{array}{c}20 \\
0\end{array}$ & $\begin{array}{l}10 \\
45\end{array}$ & $\begin{array}{l}8 \\
0\end{array}$ & $\begin{array}{l}0 \\
0\end{array}$ & $\begin{array}{l}0 \\
0\end{array}$ & -19.51 & 3.80 & 0 & & & 0 & & & & & & & & \\
\hline 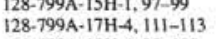 & 151.11 & 0 & 55 & 0 & $\begin{array}{l}0 \\
0\end{array}$ & 0 & & & & $\begin{array}{r}-12.02 \\
-5.40\end{array}$ & $\begin{array}{l}5.33 \\
5.06\end{array}$ & $\begin{array}{l}0 \\
0\end{array}$ & & & & & & & & \\
\hline $128-799 \mathrm{~A}-18 \mathrm{H}-4,98-100$ & 160.68 & 0 & 40 & 0 & 0 & 0 & & & & $\begin{array}{l}-3.40 \\
-9.17\end{array}$ & $\begin{array}{l}5.06 \\
4.08\end{array}$ & $\begin{array}{l}0 \\
0\end{array}$ & & & & & & & & \\
\hline \multirow{3}{*}{ 128-799A-22X-3, 52-53 } & 196.83 & 25 & 18 & 18 & 0 & 0 & -12.47 & 3.81 & 0 & & & & & & & & & & & \\
\hline & 197.32 & 0 & 45 & 0 & 0 & 0 & & & & -7.45 & 4.86 & 0 & & & & & & & & \\
\hline & 197.33 & 0 & $\begin{array}{l}40 \\
45\end{array}$ & 0 & 0 & ${ }_{0}^{0}$ & & & & $\begin{array}{r}-8.24 \\
5.9\end{array}$ & 4.51 & 0 & & & & & & & & \\
\hline $\begin{array}{l}128-799 \mathrm{~A}-23 \mathrm{X} X-4,60-61 \\
128-799 \mathrm{~A}-23 \mathrm{X}-4,63-65\end{array}$ & $\begin{array}{l}208.60 \\
208.63\end{array}$ & ${ }_{0}^{0}$ & $\begin{array}{l}45 \\
48\end{array}$ & $\begin{array}{l}0 \\
0\end{array}$ & $\begin{array}{l}0 \\
0\end{array}$ & $\begin{array}{l}0 \\
0\end{array}$ & & & & $\begin{array}{l}-5.19 \\
-5.39\end{array}$ & $\begin{array}{l}4.01 \\
4.66\end{array}$ & $\begin{array}{l}0 \\
0\end{array}$ & & & & & & & & \\
\hline $128-799 \mathrm{~A}-24 \times-7,0-3$ & 222.10 & 0 & 42 & 0 & 0 & 0 & & & & $\begin{array}{l}-3.39 \\
-4.32\end{array}$ & $\begin{array}{l}4.66 \\
4.64\end{array}$ & $\begin{array}{l}0 \\
0\end{array}$ & & & & & & & & \\
\hline $128-799 \mathrm{~A}-24 \times-7,19-21$ & 222.29 & 0 & 35 & 0 & 0 & 0 & & & & -4.25 & 4.32 & 0 & & & & & & & & \\
\hline $128-799 \mathrm{~A}-25 \mathrm{X}-4,144-146$ & 228.74 & 0 & 0 & 15 & 0 & 0 & & & & & & & -2.12 & 4.7 & & & & & & \\
\hline $128-799 \mathrm{~A}-27 \mathrm{X}-2,65-67$ & 243.55 & 0 & 45 & 0 & 0 & 0 & & & & -5.43 & 3.76 & 0 & & & & & & & & \\
\hline \multirow{3}{*}{$128-799 \mathrm{~A}-28 \mathrm{X}-1,4-12$} & $\begin{array}{l}245.51 \\
247.14\end{array}$ & $0_{0}^{0}$ & $\begin{array}{c}55 \\
0\end{array}$ & $\begin{array}{l}0 \\
0\end{array}$ & $\stackrel{0}{0}$ & $\begin{array}{c}0 \\
65\end{array}$ & & & & -4.56 & 4.75 & 0 & & & & & & -22.77 & & 100 \\
\hline & 247.15 & 0 & 0 & 0 & 0 & 70 & & & & & & & & & & & & -20.81 & 3.36 & 130 \\
\hline & 247,16 & 0 & 0 & 0 & 0 & 85 & & & & & & & & & & & & -23.70 & 5.37 & 60 \\
\hline $128-799 \mathrm{~A}-29 \mathrm{X}-1.132-136$ & 252.22 & 0 & 0 & 0 & 0 & 95 & & & & & & & & & & & & -19.81 & 4.16 & 101 \\
\hline $128-799 \mathrm{~A}-30 \mathrm{X}-3,102-108$ & 264.52 & 18 & 28 & 0 & 0 & 0 & -24.34 & 3.15 & 19 & -14.82 & 3.51 & 0 & & & & & & & & \\
\hline 128-799A-34X-3.36-38 & 300.96 & 0 & 30 & 15 & 0 & 0 & & & & .4 .93 & 3.44 & 0 & -1.62 & 49 & & & & & & \\
\hline $128-799 \mathrm{~A}-35 \mathrm{X}-4.43-45$ & 312.23 & 0 & 57 & 2 & 0 & 0 & & & & 4.63 & 4.63 & 0 & & & & & & & & \\
\hline $\begin{array}{l}128-799 \mathrm{~A}-37 \mathrm{X}-1.2-4 \\
128.79 \mathrm{~A}-39 \mathrm{X}-1-1-2\end{array}$ & $\begin{array}{l}326.62 \\
345.91\end{array}$ & ${ }_{20}^{0}$ & $\begin{array}{l}65 \\
30\end{array}$ & $\begin{array}{l}0 \\
0\end{array}$ & $\begin{array}{l}0 \\
0\end{array}$ & $\begin{array}{l}0 \\
0\end{array}$ & & & & -4.78 & 4.15 & 0 & & & & & & & & \\
\hline $\begin{array}{l}\text { 128-799A-39X-1, 1-2 } \\
128-799 \mathrm{~A}-40 \mathrm{X}-1.13-15\end{array}$ & $\begin{array}{l}345.91 \\
355.73\end{array}$ & $\begin{array}{l}20 \\
25\end{array}$ & $\begin{array}{l}30 \\
20\end{array}$ & $\begin{array}{l}0 \\
0\end{array}$ & $\begin{array}{l}0 \\
0\end{array}$ & ${ }_{0}^{0}$ & $\begin{array}{l}-20.83 \\
-19.68\end{array}$ & $\begin{array}{l}3.97 \\
3.60\end{array}$ & $\begin{array}{l}0 \\
4\end{array}$ & .10 .49 & 2.70 & 20 & & & & & & & & \\
\hline $128-799 \mathrm{~A}-49 \mathrm{X}-1.93-95$ & 443.55 & 0 & 0 & 0 & 8 & 100 & & & & & & & & & & & & -3.39 & $.7,05$ & 488 \\
\hline \multirow[t]{3}{*}{ 128-799A-49X-CC, $0-10$} & 443.60 & 0 & 0 & 0 & 10 & 75 & & & & & & & & & & & & -2.84 & -5.63 & 439 \\
\hline & $\begin{array}{l}443.64 \\
443.68\end{array}$ & 0 & 0 & 0 & 5 & 95 & & & & & & & & & & & & -2.04 & -6.54 & 471 \\
\hline & $\begin{array}{l}443.68 \\
45988\end{array}$ & 0 & 0 & 0 & 10 & 100 & & & & & & & & & & & & -2.75 & -5.73 & 443 \\
\hline $\begin{array}{l}128.799 \mathrm{~A}-50 \mathrm{X} \times-6,7-12 \\
128-799 \mathrm{~A}-51 \mathrm{X}-1.87-89\end{array}$ & $\begin{array}{l}459.88 \\
46277\end{array}$ & $0_{0}^{0}$ & $\begin{array}{r}25 \\
5\end{array}$ & ${ }_{0}^{0}$ & $\begin{array}{l}70 \\
25\end{array}$ & $\begin{array}{l}0 \\
0 \\
0\end{array}$ & & & & -1.42 & 2.37 & 32 & & & 3.5 & $\begin{array}{l}-1.5 \\
-20\end{array}$ & 386 & & & \\
\hline $128-799 \mathrm{~A}-51 \times-2,60-63$ & $\begin{array}{l}4027.00 \\
464.00\end{array}$ & o & $\begin{array}{c}5 \\
30\end{array}$ & $\begin{array}{l}0 \\
0\end{array}$ & $\begin{array}{l}25 \\
65\end{array}$ & $\begin{array}{l}0 \\
0\end{array}$ & & & & .5 .51 & 3.20 & 4 & & & $\begin{array}{l}2.4 \\
3.7\end{array}$ & -2.2. & $\begin{array}{l}404 \\
409\end{array}$ & & & \\
\hline $128-799 \mathrm{~A}-51 \times-3,2-3$ & 464.92 & 0 & 30 & 0 & 38 & 0 & & & & .4 .75 & 3.31 & 0 & & & 4.4 & -2.0 & 404 & & & \\
\hline \multirow[t]{4}{*}{ 128-799A-51X-CC, $0-35$} & 465.86 & 0 & 0 & 0 & 0 & 5 & & & & & & & & & & & & -1.09 & -6.85 & 481 \\
\hline & 465.93 & 0 & 0 & 0 & 0 & 100 & & & & & & & & & & & & 0.25 & -6.17 & 458 \\
\hline & 466.00 & 0 & ${ }_{0}^{0}$ & 0 & 0 & 100 & & & & & & & & & & & & 1.78 & -6.69 & 475 \\
\hline & $\begin{array}{l}466.10 \\
466.17\end{array}$ & $\begin{array}{l}0 \\
0\end{array}$ & $\begin{array}{l}0 \\
0\end{array}$ & $\begin{array}{l}0 \\
0\end{array}$ & $\begin{array}{l}0 \\
0\end{array}$ & $\begin{array}{l}100 \\
100\end{array}$ & & & & & & & & & & & & $\begin{array}{l}2.88 \\
1.27\end{array}$ & $\begin{array}{l}-5.20 \\
-5.90\end{array}$ & $\begin{array}{l}424 \\
499\end{array}$ \\
\hline 128-799B-6R-3, 86-92 & 498.46 & 0 & 10 & 0 & 40 & 0 & & & & & & & & & 3.8 & -2.4 & 419 & & -5.90 & \\
\hline & 498.47 & 0 & 35 & 0 & 15 & 0 & & & & .5 .86 & 3.57 & 0 & & & 3.4 & 2.8 & 431 & & & \\
\hline $128-799 \mathrm{~B}-7 \mathrm{R}-1,79-81$ & 500.49 & 0 & 40 & 0 & 7 & 0 & & & & -7.21 & 3.83 & 0 & & & & & & & & \\
\hline & 501.97 & 8 & 10 & 0 & 48 & 0 & & & & & & & & & 4.0 & -2.3 & 414 & & & \\
\hline 128-7998-7R-2, 99-101 & $\begin{array}{l}502.19 \\
50420\end{array}$ & $\begin{array}{l}15 \\
15\end{array}$ & $\begin{array}{l}10 \\
12\end{array}$ & $\begin{array}{l}0 \\
0\end{array}$ & $\begin{array}{l}45 \\
26\end{array}$ & $\begin{array}{l}0 \\
0\end{array}$ & $\begin{array}{l}-16.87 \\
-1600\end{array}$ & $\begin{array}{l}2.82 \\
1.27\end{array}$ & $\begin{array}{l}30 \\
84 \\
84\end{array}$ & & & & & & & & & & & \\
\hline $\begin{array}{l}128-7999-7 R-4,0-2 \\
128-799 B-10 R-1,36-46\end{array}$ & $\begin{array}{l}504.20 \\
528.96\end{array}$ & $\begin{array}{c}15 \\
0\end{array}$ & $\begin{array}{r}12 \\
0\end{array}$ & 0 & $\begin{array}{l}26 \\
50\end{array}$ & 22 & -16.01 & & & & & & & & 5.1 & -1.6 & 388 & & & \\
\hline & 528.97 & 0 & 0 & 0 & 55 & 8 & & & & & & & & & 4.3 & -1.5 & 386 & & & \\
\hline & 528.98 & 0 & 0 & 0 & 42 & 15 & & & & & & & & & 4.6 & -1.6 & 390 & & & \\
\hline $238-7998-108-2,71-76$ & $\begin{array}{l}528.99 \\
5081\end{array}$ & 0 & 0 & 0 & $\begin{array}{l}46 \\
25\end{array}$ & $\begin{array}{l}8 \\
0\end{array}$ & & & & & & & & & 5.1. & -1.3 & 379 & & & \\
\hline $128-7998-10 R-2,7-76$ & 530.81 & 0 & 0 & 0 & 23 & 0 & & & & & & & & & -3.5 & -1.1 & 373 & & & \\
\hline
\end{tabular}


Table 1 (continued).

\begin{tabular}{|c|c|c|c|c|c|c|c|c|c|c|c|c|c|c|c|c|c|c|}
\hline & 533.00 & 15 & 5 & 0 & 30 & 5 & 13.83 & 231 & 49 & & & & & & & & & \\
\hline \multirow{3}{*}{$128-799 \mathrm{~B}-11 \mathrm{R}-5.500-104$} & 534.24 & 8 & ${ }_{4}^{4}$ & 0 & 50 & 4 & $-13,83$ & 2.31 & & & & & 4.5 & -0.7 & 358 & & & \\
\hline & 545.30 & 0 & 5 & 0 & 60 & 5 & & & & & & & 3.5 & -2.1 & 407 & & & \\
\hline & 545.31 & 0 & 0 & 0 & 25 & 0 & & & & & & & 3.0 & -3.6 & 458 & & & \\
\hline \multirow{3}{*}{$\begin{array}{l}128-799 \mathrm{~B}-11 \mathrm{R}-7,1-4 \\
128-799 \mathrm{~B}-15 \mathrm{R}-5,53-55\end{array}$} & 547.31 & 0 & 20 & 0 & 65 & 0 & & & & -2.41 & 2.64 & 23 & 3.8 & -1.1 & 373 & & & \\
\hline & $\begin{array}{l}553.19 \\
58353\end{array}$ & 10 & is & 0 & 22 & 0 & -16.31 & 1.68 & 70 & & & & & & & & & \\
\hline & $\begin{array}{l}583.53 \\
583.54\end{array}$ & 26 & $\stackrel{0}{0}$ & $\stackrel{0}{0}$ & 10 & ${ }_{0}^{0}$ & $\begin{array}{l}-15.52 \\
.15 .58\end{array}$ & 2.03 & 58 & & & & & & & & & \\
\hline \multirow{5}{*}{$\begin{array}{l}\text { 128-7998-17R-4. } 102-104 \\
128.799 \mathrm{~B}-18 \mathrm{R}-5.5-8 \\
128-799 \mathrm{~B}-19 \mathrm{R}-6.85-89 \\
128-799 \mathrm{~B}-20 \mathrm{R}-2.263-72\end{array}$} & 601.82 & 0 & 30 & 0 & 6 & 0 & -15.58 & 2.10 & 56 & -4.57 & 4.00 & 0 & & & & & & \\
\hline & 611.95 & 0 & 30 & 0 & 6 & 0 & & & & -4.77 & 4.11 & 0 & & & & & & \\
\hline & 623.95 & 0 & 0 & 0 & 0 & 90 & & & & & . & 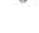 & & & & .2 .95 & -8.87 & 551 \\
\hline & 627.35 & 5 & 0 & 0 & 40 & 0 & & & & & & & -6.0 & -3.6 & 458 & & & \\
\hline & $\begin{array}{l}627.36 \\
63.187\end{array}$ & 0 & 5 & 0 & 22 & 5 & & & & & & & -6.4 & -3.1 & 443 & & & \\
\hline \multirow{3}{*}{ 128-799B-20R-5. $62-73$} & $\begin{array}{l}631.82 \\
631.83\end{array}$ & 0 & 0 & 0 & 20 & 15 & & & & & & & -5.4 & -5.2 & 513 & .6 .10 & -5.69 & 441 \\
\hline & $\begin{array}{l}63.83 \\
63.184\end{array}$ & 0 & ${ }_{0}^{0}-2-3$ & ${ }_{0}^{0}$ & $\begin{array}{l}30 \\
35\end{array}$ & 20 & & & & & & & -4.6 & 4.5 & 491 & -6.63 & -4.11 & 387 \\
\hline & $\begin{array}{l}631.84 \\
631.15\end{array}$ & $\begin{array}{l}0 \\
0\end{array}$ & $\begin{array}{l}0 \\
0\end{array}$ & $\begin{array}{l}0 \\
0\end{array}$ & 35 & 22 & & & & & & & -4.3 & $\begin{array}{r}4.6 \\
-45\end{array}$ & $\begin{array}{l}493 \\
489\end{array}$ & $\begin{array}{r}-5.86 \\
560\end{array}$ & $\begin{array}{l}-5.54 \\
-585\end{array}$ & 436 \\
\hline \multirow{3}{*}{ 128-7998-20R-6, $127-134$} & $\begin{array}{l}63.189 \\
633.97\end{array}$ & 0 & 0 & 0 & $\begin{array}{l}22 \\
40\end{array}$ & $\begin{array}{r}15 \\
5\end{array}$ & & & & & & & $\begin{array}{l}-4.3 \\
-4.4\end{array}$ & -4.7 & $\begin{array}{l}489 \\
498\end{array}$ & .5 .69 & -5.85 & 447 \\
\hline & $\begin{array}{l}033,98 \\
633\end{array}$ & 0 & 0 & 0 & 25 & 0 & & & & & & & .5 .4 & -3.7 & 462 & & & \\
\hline & 636.96 & 0 & 0 & 0 & 35 & 0 & & & & & & & -3.9 & -3.2 & 446 & & & \\
\hline $128-799 \mathrm{~B}-24 \mathrm{R}-1,99-101$ & 664.79 & 0 & 35 & 0 & 10 & 0 & & & & .4 .16 & 3.14 & 6 & & & & & & \\
\hline $128-7998-27 R-7,40-42$ & 701.90 & 2 & 0 & 0 & 0 & 70 & & & & & & & & & & -5.60 & -9.73 & 581 \\
\hline $128-799 \mathrm{~B}-30 \mathrm{R}-1,66-68$ & 722.06 & 0 & 0 & 0 & 5 & 100 & & & & & & & & & & -14.99 $>$ > & 0.57 & 225 \\
\hline \multirow[t]{3}{*}{ |28-799B-3|R-I. $13-22$} & 730.93 & 0 & 0 & 0 & 0 & 100 & & & & & & & & & & -13.98 & -2.10 & 317 \\
\hline & 730.94 & 0 & 0 & 0 & 0 & 100 & & & & & & & & & & -13.74 & -2.00 & 314 \\
\hline & 730.95 & 0 & 0 & 0 & 0 & 100 & & & & & & & & & & -13.80 & $-2,30$ & 324 \\
\hline 128-799B-32R-1. 68-70 & 741.17 & 0 & 0 & 0 & 0 & 100 & & & & & & & & & & -15.94 & -5.08 & 420 \\
\hline 128-7998-34R-2, $142-144$ & 762.72 & 0 & 0 & 0 & 0 & 100 & & & & & & & & & & -11.86 & -4.66 & 406 \\
\hline 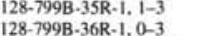 & 769.51 & 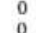 & ${ }_{0}^{0}$ & 0 & ${ }_{0}^{0}$ & 80 & & & & & & & & & & -13.10 & $\begin{array}{r}-2.33 \\
.58\end{array}-1$ & 325 \\
\hline 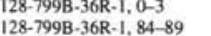 & $\begin{array}{l}779,20 \\
7804\end{array}$ & $\begin{array}{l}0 \\
0\end{array}-1$ & $\begin{array}{l}0 \\
0\end{array}$ & $\begin{array}{l}0 \\
0\end{array}$ & 15 & 100 & & & & & & & -74 & .28 & 433 & -10.85 & -5.48 & 434 \\
\hline $128-799 \mathrm{~B}-39 \mathrm{R}-\mathrm{I}, 68-70$ & $\begin{array}{l}780.04 \\
808.78\end{array}$ & $0_{0}^{0}-a x$ & 0 & 0 & 12 & 0 & & & & & & & $\begin{array}{l}-1.4 \\
-1.8\end{array}$ & 06 & $\begin{array}{l}433 \\
314\end{array}$ & & & \\
\hline $128-799 \mathrm{~B}-45 \mathrm{R}-\mathrm{I}, 22-24$ & 866.02 & 0 & 0 & 0 & 0 & 80 & & & & & & & & & & -5.36 & -7.36 & 499 \\
\hline \multirow{3}{*}{$128-799 \mathrm{~B}-48 \mathrm{R}-2,76-87$} & 896.86 & 0 & 0 & 0 & 0 & 70 & & & & & & & & & & .745 & -8.26 & 530 \\
\hline & 896.87 & 0 & 0 & 0 & 0 & 65 & & & & & & & & & & -7.53 & -8.15 & 526 \\
\hline & 896.88 & 0 & 0 & 0 & 0 & 90 & & & & & & & & & & .8 .22 & -7.91 & 518 \\
\hline \multirow[t]{4}{*}{$128-799 \mathrm{~B}-48 \mathrm{R}-2,87-95$} & 896.97 & 0 & 0 & 0 & 0 & 80 & & & & & & & & & & -11.90 & .2 .87 & 344 \\
\hline & 896.98 & 0 & 0 & 0 & 0 & 70 & & & & & & & & & & -12.48 & -2.10 & 317 \\
\hline & 896.99 & 0 & 0 & 0 & 0 & 85 & & & & & & & & & & -12.83 & -1.50 & 297 \\
\hline & 897.01 & 0 & 0 & 0 & 0 & 90 & & & & & & & & & & -9.19 & -6.34 & 464 \\
\hline \multirow{2}{*}{ 128-799B-52R-1, $147-150$} & 934.37 & 0 & 0 & 0 & 0 & 100 & & & & & & & & & & -4.19 & -5.37 & 440 \\
\hline & $\begin{array}{l}934.58 \\
92475\end{array}-10$ & 0 & 0 & 0 & 0 & 48 & & & & & & & & & & -14.95 & -3.90 & 380 \\
\hline $128-799 \mathrm{~B}-52 \mathrm{R}-2,31-34$ & $\begin{array}{l}934.75 \\
93482\end{array}$ & 0 & ${ }_{0}^{0}-2 x-3$ & ${ }_{0}^{0}$ & ${ }_{0}^{0}$ & $\begin{array}{l}90 \\
60\end{array}$ & & & & & & & & & & -15.16 & $\begin{array}{r}-2.90 \\
-075\end{array}$ & 345 \\
\hline 128-799B-54R-1, 66-68 & $\begin{array}{l}934.82 \\
952.86\end{array}$ & 0 & ${ }_{5}^{0}$ & $\begin{array}{l}0 \\
0\end{array}$ & $\begin{array}{l}0 \\
0\end{array}$ & $\begin{array}{l}60 \\
10\end{array}$ & & & & & & & & & & -15.04 & -0.73 & 270 \\
\hline \multirow{3}{*}{ 128-799B-54R-CC, 3-8 } & $\begin{array}{r}952.280 \\
956.60\end{array}$ & $\begin{array}{l}0 \\
0\end{array}$ & 0 & $\begin{array}{l}0 \\
0\end{array}$ & ${ }_{0}^{0}$ & $\begin{array}{l}10 \\
60\end{array}$ & & & & & & & & & & $\begin{array}{l}-1.4 .88 \\
-11.86\end{array}$ & $\begin{array}{l}-0.06 \\
-3.06\end{array}$ & $\begin{array}{l}270 \\
351\end{array}$ \\
\hline & $\begin{array}{l}956.60 \\
956.61\end{array}$ & 0 & 0 & 0 & 0 & & & & & & & & & & & $\begin{array}{l}-15.180 \\
-15\end{array}$ & $\begin{array}{r}-4.90 \\
\end{array}$ & 415 \\
\hline & 1032.63 & 0 & 0 & 0 & 0 & 100 & & & & & & & & & & $\begin{array}{r}4.89 \\
\end{array}$ & -7.07 & 489 \\
\hline \multirow{2}{*}{$\begin{array}{l}128-799 \mathrm{~B}-622-3-3,13-15 \\
128-799 \mathrm{~B}-63 \mathrm{R}-1,110-118\end{array}$} & 1040.20 & 0 & 0 & 0 & 0 & 40 & & & & & & & & & & 0.58 & -4.29 & $\begin{array}{l}793 \\
393\end{array}$ \\
\hline & 1040.22 & 0 & 0 & 0 & 0 & 65 & & & & & & & & & & -2.66 & -5.61 & 439 \\
\hline \multirow{2}{*}{ 128-799B-64R-1, 19-22 } & 1048.99 & 15 & 0 & 0 & 0 & 70 & -8.93 & -7.95 & 402 & & & & & & & -4.91 & -8.21 & 528 \\
\hline & 1049.00 & 5 & 0 & 0 & 0 & 50 & -11.03 & -11.14 & 512 & & & & & & & & & \\
\hline $128-799 \mathrm{~B}-64 \mathrm{R}-1,112-114$ & 1049.92 & 0 & 0 & 0 & 0 & 65 & & & & & & & & & & 4.92 & -7.52 & 504 \\
\hline
\end{tabular}



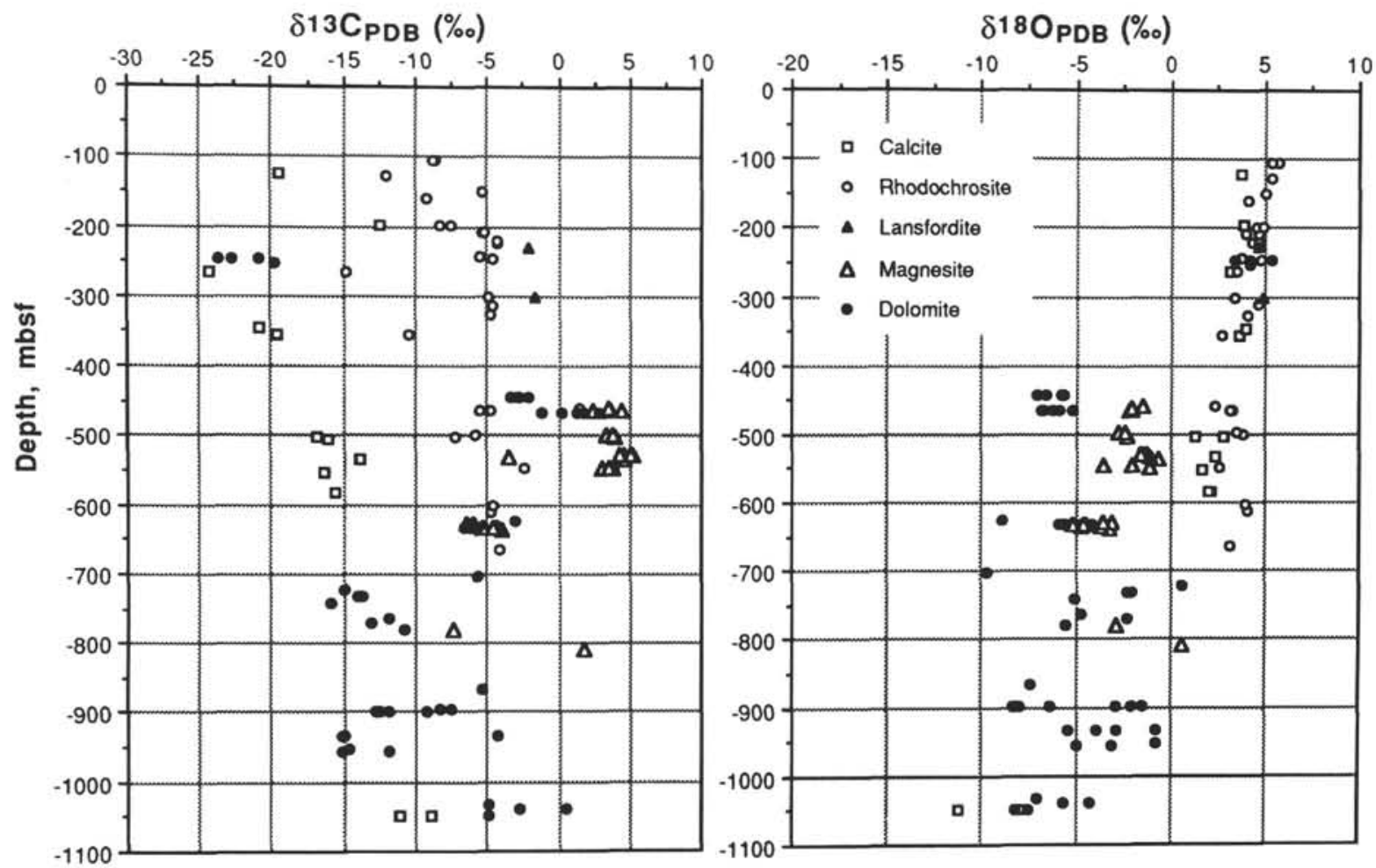

Figure 11. Variation in carbon and oxygen isotope compositions of diagenetic carbonates plotted against the depth of occurrence.

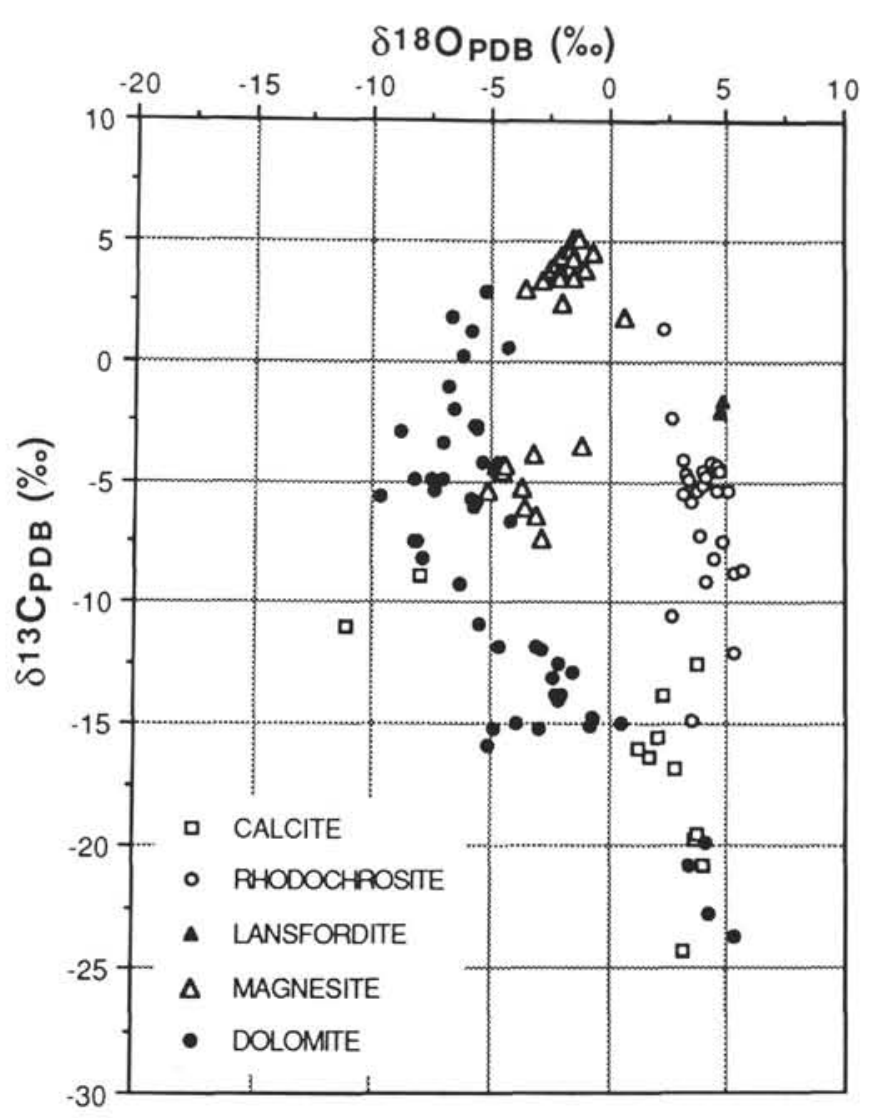

Figure $12 . \delta^{13} \mathrm{C}$ and $\delta^{18} \mathrm{O}$ cross-plot for Site 799 diagenetic carbonates. in the range of deeply formed dolomites. Magnesites, which formed at about 300 to 450 mbsf, are also characterized by relatively heavy carbon isotopic composition. In summary, Figure 16 demonstrates that the carbon isotope composition of the Site 799 carbonates decreases rapidly with depth in the shallower sediments ( $<20-50 \mathrm{mbsf})$, gradually increases at intermediate depths and approaches shallow burial values of about $0 \%$ at around $500 \mathrm{mbsf}$.

The $\delta^{13} \mathrm{C}$ depth profile of the Site 799 carbonates is similar to that of diagenetic carbonates from the inner slope sediments of the Japan Trench (Matsumoto and Matsuhisa, 1985), and significantly, quite consistent with the depth profile of $\delta^{13} \mathrm{C}$ of dissolved carbonates in the interstitial waters of the anoxic sediments of the Blake Outer Ridge (Claypool and Threlkeld, 1983).

The zone of rapid decrease in $\delta^{13} \mathrm{C}$ values corresponds to the sulfate reduction zone, where organic carbon is generally decomposed with the bacterial reduction of sulfate (e.g., Irwin et al., 1977; Hudson, 1977; Matsumoto and Matsuhisa, 1980; Curtis and Coleman, 1986). As a result of this reaction, concentrations of bicarbonate and alkalinity would increase within this zone, promoting the precipitation of carbonates. The $\delta^{13} \mathrm{C}$ values of diagenetic carbonates becomes more and more negative due to the incorporation of increasing amounts of bicarbonate derived from organic carbon. The anaerobic methane oxidation zone, in which alkalinity dramatically increases and $\delta^{13} \mathrm{C}$ shows the minimum value as a result of methane consumption by sulfate reduction (Raiswell, 1987), occurs at around 20-50 mbsf. This zone appears at 15 mbsf in the Blake Outer Ridge sediments (Claypool and Threlkeld, 1983) and at about $80 \mathrm{mbsf}$ in the Japan Trench sediments (Matsumoto and Matsuhisa, 1985).

The zone of gradual increase in $\delta^{13} \mathrm{C}$ with depth represents the onset of methanogenesis, whereby organic carbon is dominantly decomposed through methane fermentation driven by methane bacteria. The equilibrium fractionation of the carbon isotopes between $\mathrm{CH}_{4}$ and $\mathrm{CO}_{2}$ in the interstitial waters is very large (Claypool and Threlkeld, 1983); $\mathrm{CH}_{4}$ usually being greatly depleted in ${ }^{13} \mathrm{C}$ by approximately $-50 \%$ o to $-70 \%$ o. As a result, the diagenetic carbon- 


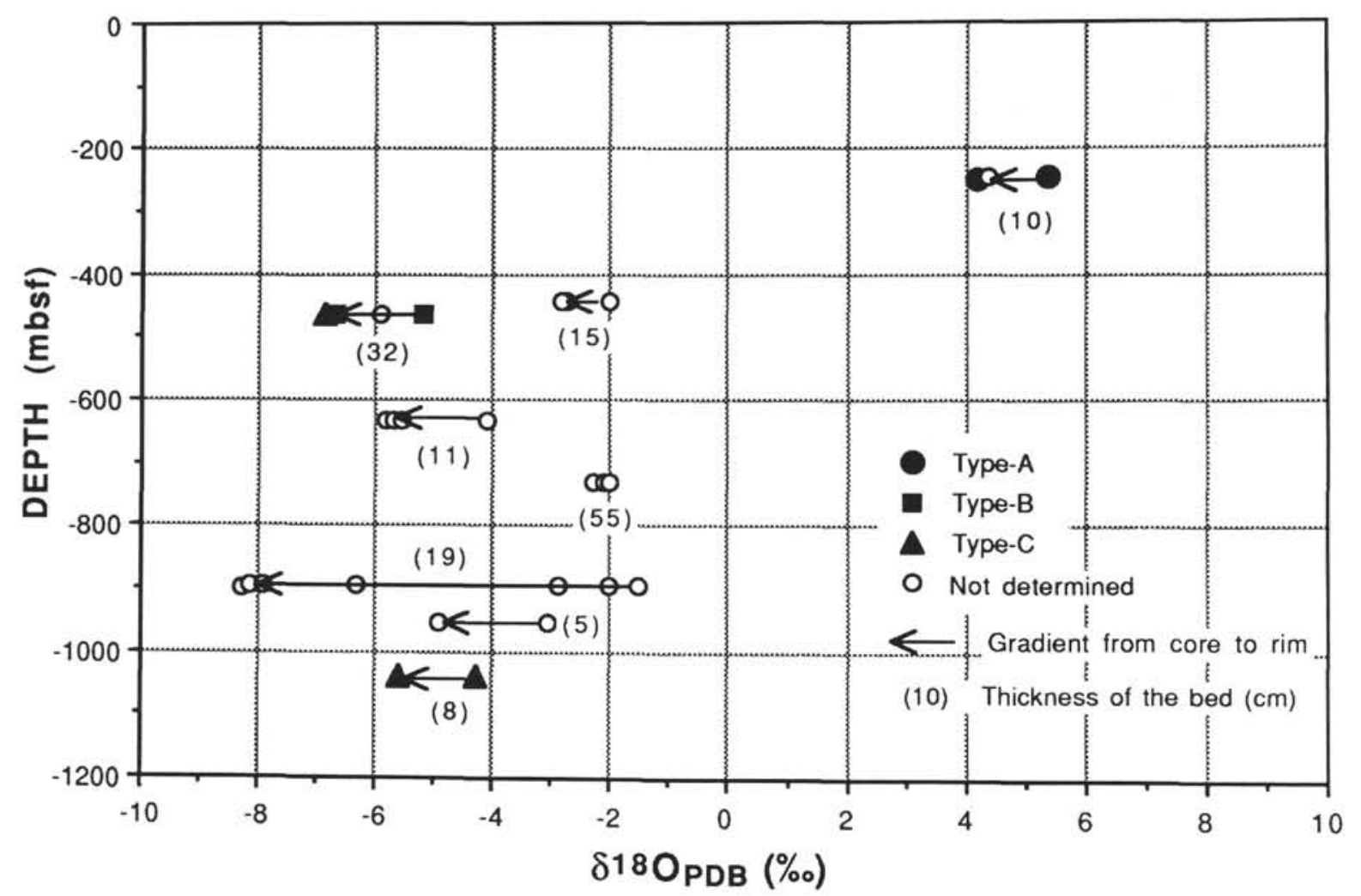

Figure 13. The gradient in $\delta^{18} \mathrm{O}$ values of dolomite within dolomite layers. Arrows indicate the direction from the core to the margin. The degree of recrystallization (type A, B, or C) is also given for selected samples.
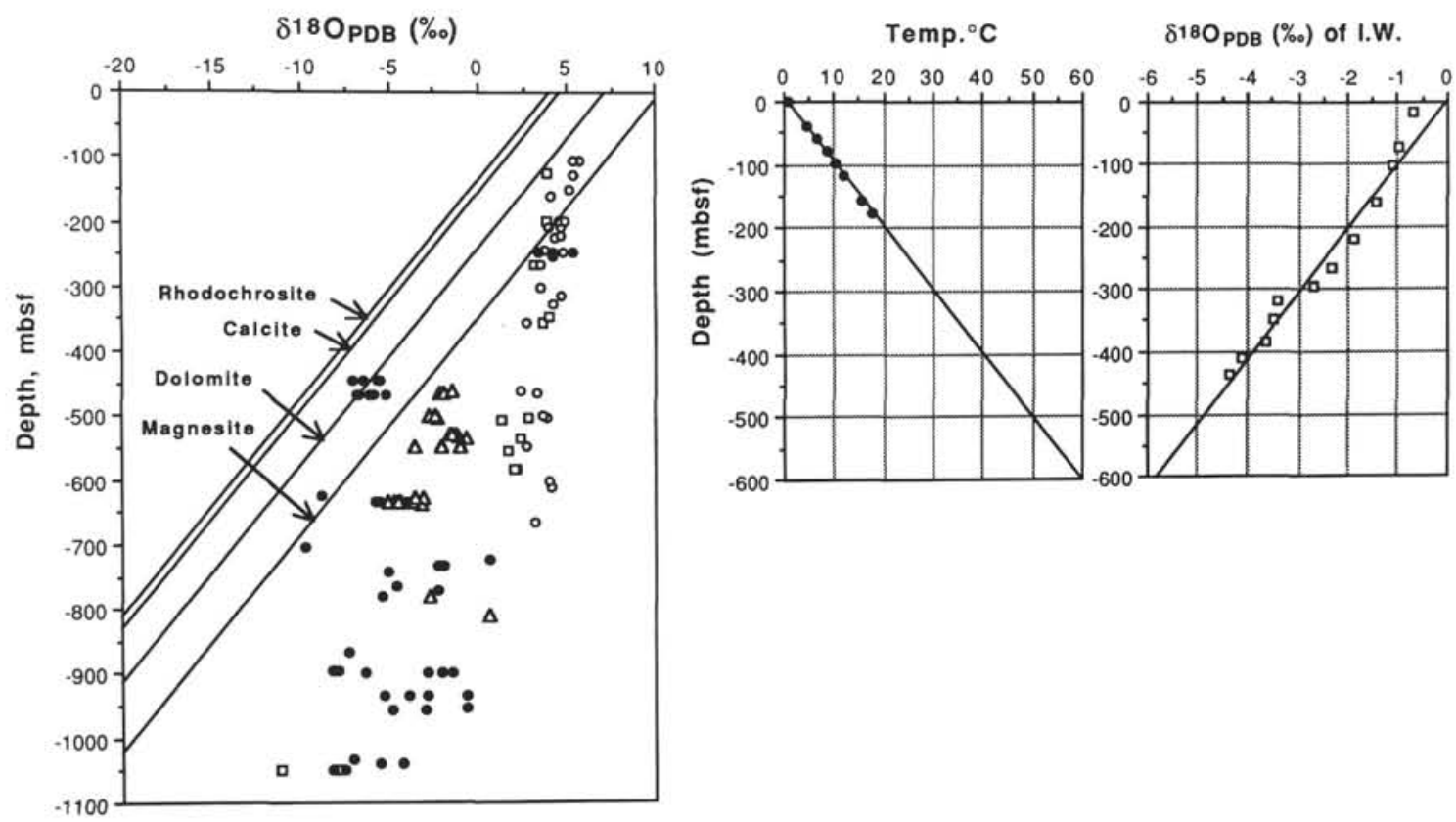

Figure 14. In the plot of oxygen isotope composition against depth, the lines show the relation between equilibrium $\delta^{18} \mathrm{O}$ values and the depth of precipitation of rhodochrosite, calcite, dolomite, and magnesite. The equilibrium ${ }^{18} \mathrm{O}$ values decrease with depth at a virtually constant rate of $-3.7 \% \mathrm{oo} / 100 \mathrm{~m}$, reflecting elevated temperatures and the systematic decrease in $\delta^{18} \mathrm{O}$ of waters. For comparison, observed $\delta^{18} \mathrm{O}$ values are also plotted against the depth of occurrence. Note that almost all of the samples are more enriched in ${ }^{18} \mathrm{O}$ compared with the expected equilibrium values. 


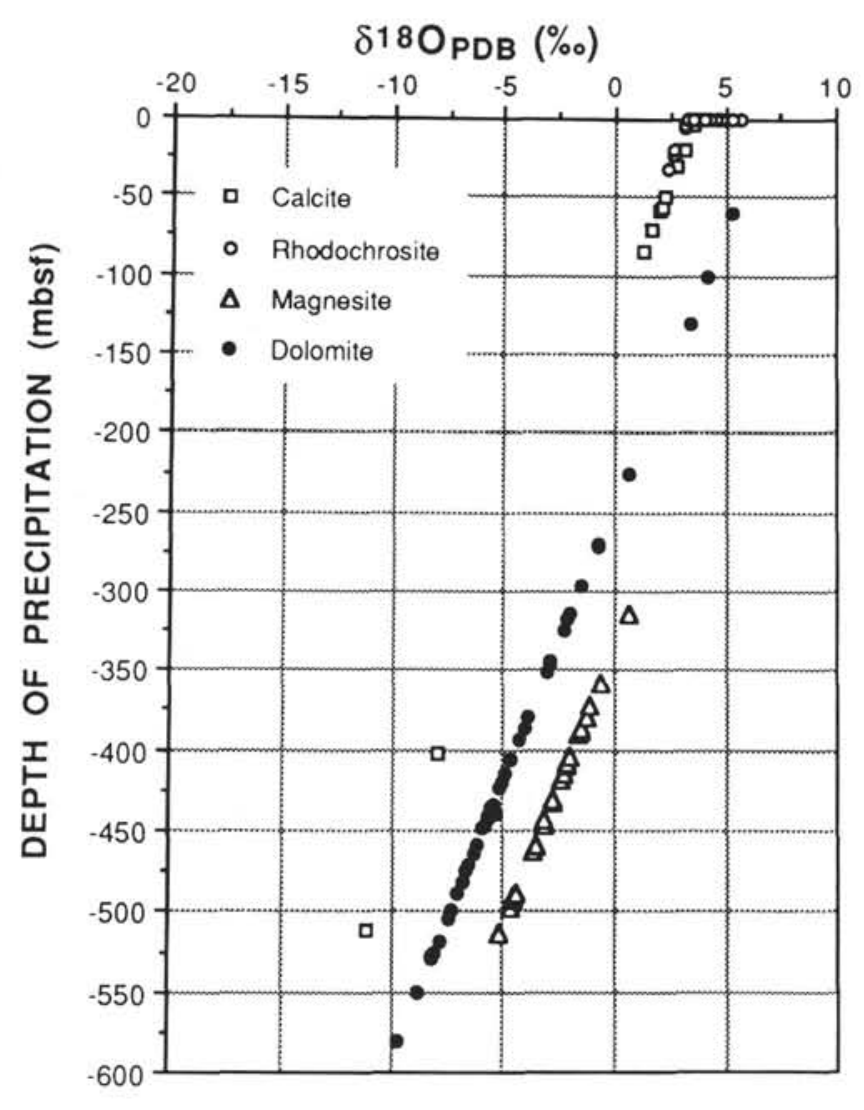

Figure 15. The depth of precipitation of calcite, rhodochrosite, dolomite, and magnesite. Observed $\delta^{18} \mathrm{O}$ values are projected on the respective curves in Figure 14. ates formed in the methane fermentation zone are characterized by relatively heavy $\delta^{13} \mathrm{C}$ values up to about $15 \%$ due to the increasing contribution of residual bicarbonate from the equilibrium exchange between $\mathrm{CH}_{4}$ and $\mathrm{CO}_{2}$.

\section{Manganese Accumulation and Rhodochrosite Formation}

The brick-red diatomaceous clay layers $3-$ to $12-\mathrm{cm}$ thick in near-surface sediments $0-1$ mbsf at Site 799 are characterized by high concentrations of manganese $(0.3 \%-2.0 \% \mathrm{MnO})$ and iron $\left(6.2 \%-13.0 \% \mathrm{Fe}_{2} \mathrm{O}_{3}\right)$ (Matsumoto et al., unpubl. data). Preliminary analysis of the rare-earth elements revealed that these layers are more enriched in cerium relative to the other REEs, with a positive $\mathrm{Ce}$-anomaly $(\mathrm{Ce} / \mathrm{Ce} *=1.5-1.9)$. The positive cerium anomaly of sediments is thought to be a diagnostic parameter of active hydrogenous accumulation, as $\mathrm{Ce}$ is readily oxidized in the well-oxygenated water and tends to coprecipitate with manganese and iron on the seafloor.

Figure 17 illustrates the depth profile of $\mathrm{Ce}$ anomaly of the Site 799 sediments. The Units II and III sediments, which are variably bioturbated, are characterized by positive Ce anomaly, whereas those of the Units I and IV, exclusive of the near surface Mn-rich layers, are relatively poor in cerium with the $\mathrm{Ce} / \mathrm{Ce}$ * values of about 1.0 . Significantly, Ce-enriched sediments in Units II and III also contain rhodochrosite as the predominant carbonate phase. In contrast, dolomites tend to accrete in Ce-depleted sediments. These associations indicate that manganese in rhodochrosite was originally accumulated as a hydrogenous component when the bottom water was well oxygenated. The high manganese concentrations of Site 799 carbonates can be ascribed to the strong oxic conditions that prevailed in the bottom waters of the Kita-Yamato Trough during late middle Miocene to late Pliocene.

The manganese that accumulated on the seafloor as oxideshydroxides was readily reduced upon burial in organic-carbon-rich, anoxic sediments. Coupled with an excess alkalinity produced by the

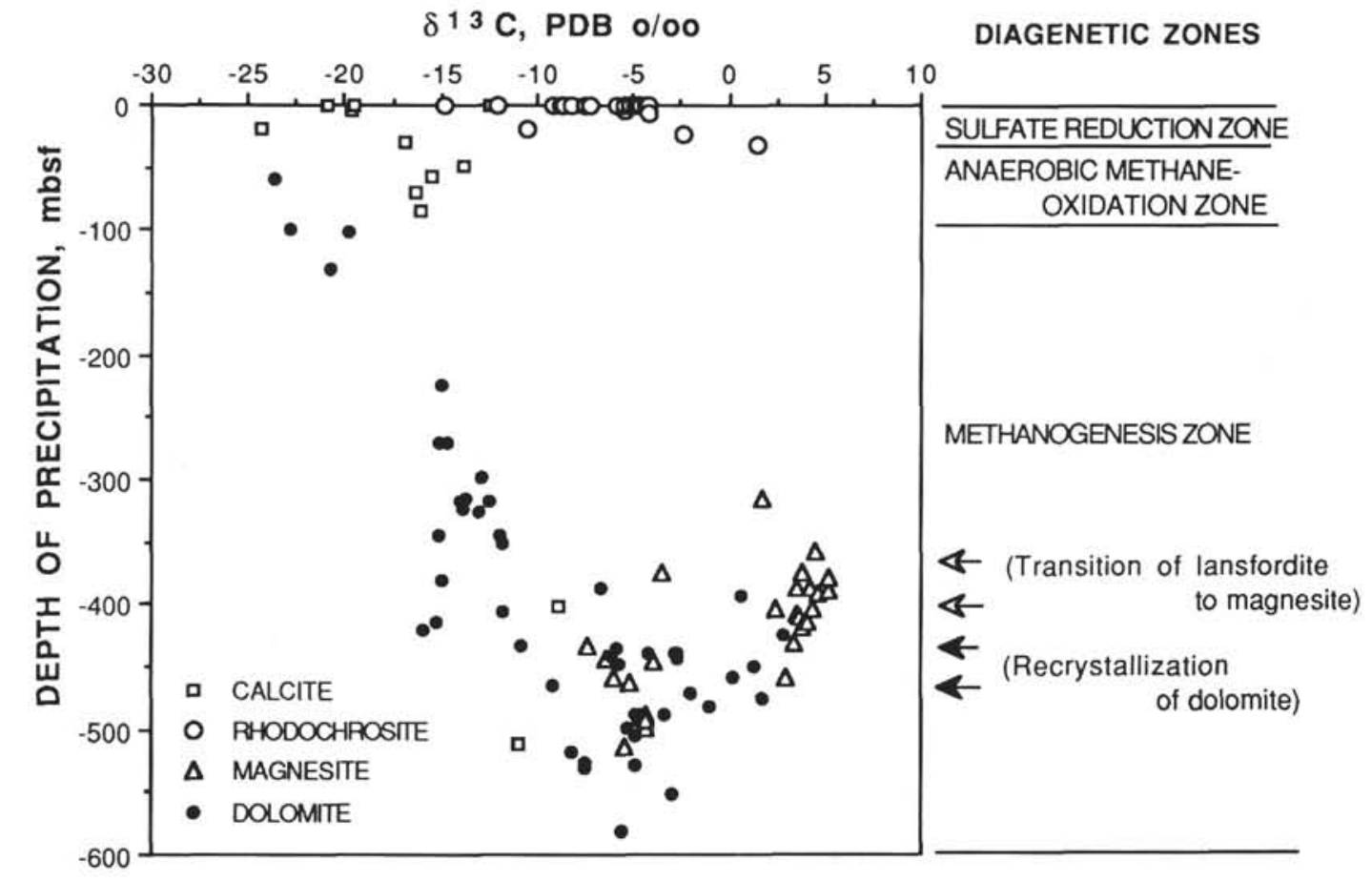

Figure 16. Variation in the $\delta^{13} \mathrm{C}$ values of diagenetic carbonates with depth of precipitation. 

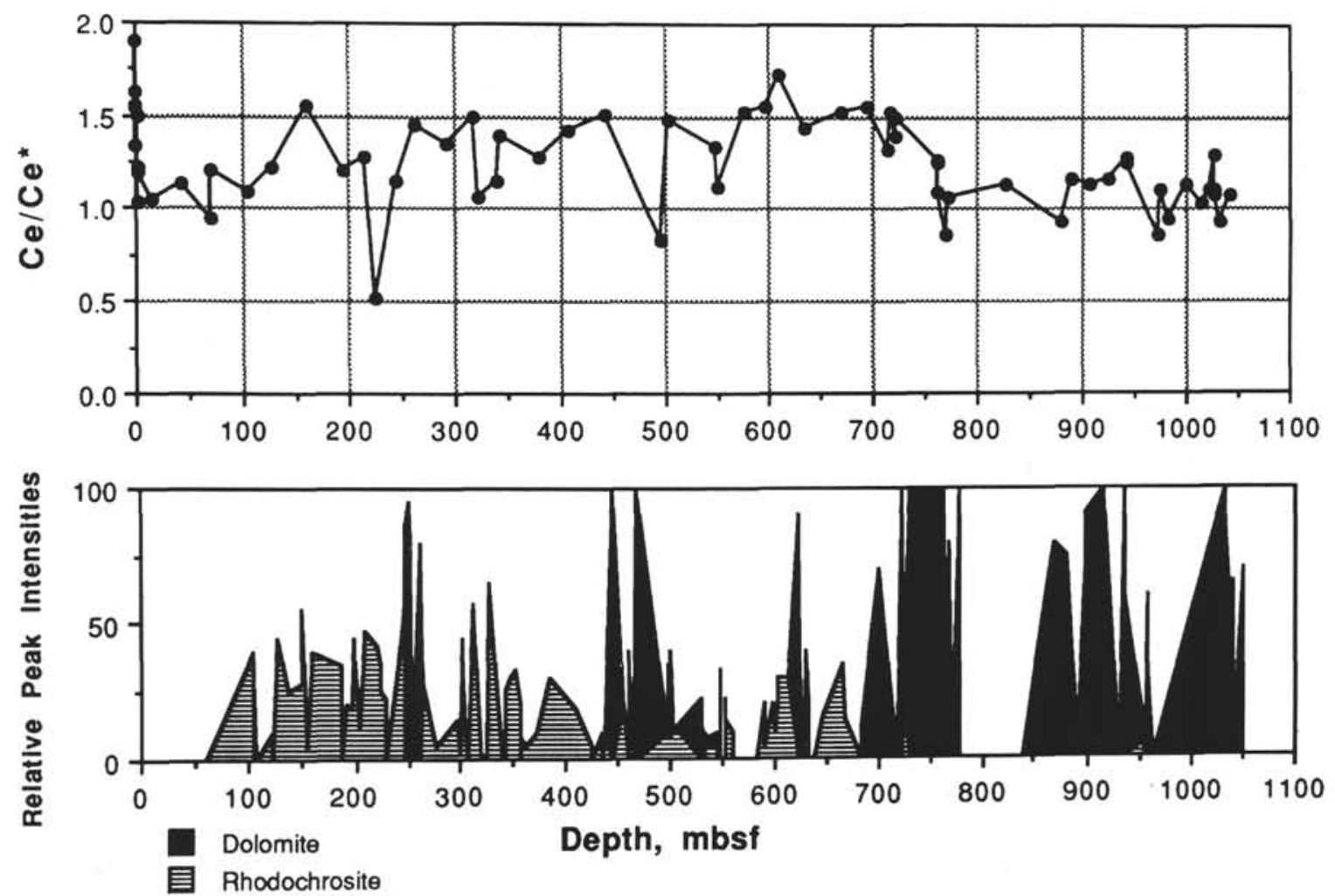

Figure 17. Relation between the carbonate mineralogy and Ce anomaly of the host sediments of Site 799. A positive Ce anomaly is recognized between about 100 and $750 \mathrm{mbsf}$, in which rhodochrosite is the dominant diagenetic carbonate. Distinct anomalies are not observed for the dolomite-rich intervals below $700 \mathrm{mbsf}$. Note the correlation between the negative $\mathrm{Ce}$ anomaly and dolomite layers in lithologic Units II and III. Ce/Ce* ratios were taken from Minai et al. (this volume).

intensive sulfate reduction of organic matter and $\mathrm{Mn}^{4+}$ reduction, the $\mathrm{Mn}^{2+}$ was precipitated as $\mathrm{Mn}$-carbonate, forming rhodochrosite nodules and layers in the near surface sediments $(<32 \mathrm{mbsf})$. The high $\mathrm{Ca}$ content $(22-40 \mathrm{~mol} \%)$ of the rhodochrosite might reflect high $\mathrm{Ca}$ concentrations derived partly from the dissolution of biogenic carbonates and partly from the overlying seawater. Iron-oxides and hydroxides were transformed to sulfide prior to rhodochrosite precipitation, as indicated by the composite nodules with a pyritic core and rhodochrosite rind.

\section{Lansfordite and Magnesite Formation}

The mineral lansfordite has not been convincingly identified in the present study; its chemical composition has not been precisely established and its crystal habit has not been examined. However, on the basis of the combined evidence of the textures and particularly XRD data, the hydrous, iron- and manganese-containing Mg carbonates were presumably precipitated at relatively shallow burial levels and were subsequently transformed to anhydrous, ferromanganoan magnesite (breunnerite), which formed layers occasionally encrusting rhodochrosite nodules. The depth of magnesite formation, $350-$ $510 \mathrm{mbsf}$ (Fig. 15), is considered to have been the depth of transformation. A dramatic peak shift for the $\mathrm{Mg}$ carbonates was recorded in X-ray diffractograms for samples recovered at about $435 \mathrm{mbsf}$ (Fig. 7). This indicates that the probable transformation of lansfordite to magnesite occurred at about $435 \mathrm{mbsf}$ and $43^{\circ} \mathrm{C}$ based on the measured geothermal gradient of $98^{\circ} \mathrm{C} / \mathrm{km}$ (Shipboard Scientific Party, 1990a, f, g).

The mechanism and conditions of lansfordite precipitation are puzzling. The $\mathrm{Mg}$ concentration of the interstitial water should increase and reach a critical saturation value to form $\mathrm{Mg}$-carbonates. Müller et al. (1972) reported that the primary magnesite and nesque- honite $\left(\mathrm{MgCO}_{3} \cdot 3 \mathrm{H}_{2} \mathrm{O}\right)$ precipitate when the $\mathrm{Mg} / \mathrm{Ca}$ ratio in the water is greater than 20 , whereas dolomite precipitates when the ratio is between 2 and about 12 . The $\mathrm{Mg} / \mathrm{Ca}$ ratio of the seawater is about five, and indeed, dolomite is the most common, magnesium-bearing, diagenetic carbonate found in organic-carbon-rich marine sediments, such as in the Neogene biosiliceous sections of the circum-Pacific region (e.g., Pisciotto and Mahoney, 1981), On'nagawa Formation in northern Japan (Matsumoto and Matsuda, 1987), and the Monterey Formation in California (e.g., Murata $\in$ t al., 1969; Baker and Burns, 1985). Why did lansfordite or magnesite form instead of dolomite in the upper middle and upper Miocene and Pliocene sediments at Site 799?

Magnesite and hydrous Mg-bearing carbonates such as hydromagnesite, lansfordite, and nesquehonite are usually considered to be evaporite minerals precipitated from concentrated, hyper-saline waters, with extremely high $\mathrm{Mg}$ concentration and high $\mathrm{Mg} / \mathrm{Ca}$ ratio (Müller et al., 1972; Pueyo et al., 1987). Japan Sea has been a deep, semiclosed, silled, marine basin for at least the last 20 m.y. Freshwater diatoms have been reported from the later Miocene sediments on the flank of Kita-Yamato Bank (Burkle and Akiba, 1978) and from the Unit II (late Miocene) at Site 799 (Shipboard Scientific Party, $1990 \mathrm{a}, \mathrm{f}, \mathrm{g}$ ), but they are thought to have been redeposited (Shipboard Scientific Party, 1990a, f, g). The presence of the redeposited freshwater diatoms suggests the possibility that portions of the Yamato Rise emerged during the late Miocene. However, there are no strong indications that the Kita-Yamato Trough basin was isolated from the rest of Japan Sea by eustatic sea-level fall and precipitated evaporite minerals by effective evaporation. On the contrary, the upper Miocene sediments at Site 799 are thought to have accumulated under normal marine, moderately- to well-oxygenated conditions as evidenced by common to abundant bioturbations. The in-situ benthic foraminifers suggest a lower-to-middle bathyal (1500-2000 m) water depths at this site during for the early to middle Miocene, and lower bathyal 
(>2000 m) during the late Miocene, Pliocene, and Quaternary (Shipboard Scientific Party, 1990a, f, g).

Lansfordite and nesquehonite were first found and identified in a coal mine in Pennsylvania (Lippman, 1973) where the formation waters are thought to have high alkalinity. Alderman (1965) obtained artificial hydrous $\mathrm{Mg}$ carbonates only by increasing the alkalinity of the water by adding excess sodium carbonate to seawater without increasing the $\mathrm{Mg} / \mathrm{Ca}$ ratio of the water. Ohmori (1991) also synthesized lansfordite and nesquehonite instead of dolomite by adding $\mathrm{NaHCO}_{3}$ to seawater at room temperatures.

Magnesite is abundant in Lithologic Unit III, particularly between 450 and 650 mbsf. Significantly, this depth interval corresponds to the section with highest organic carbon (Fig. 18). Lansfordite and magnesite commonly occur in the rhodochrosite-bearing, Ce-enriched sediments of Units II and III (Figs. 17 and 18), which deposited under well-oxygenated conditions. This indicates that the oxic sediment layer developed on the organic-carbon-rich sediments during the deposition of Units II and III. Under these conditions, the massive consumption of abundant organic matter and reduction of $\mathrm{Mn}^{4+}$ would occur in the near-surface sediments and alkalinity, $\mathrm{HCO}_{3}-$, and $\mathrm{pH}$ values of the sulfate reduction zone were increased. Furthermore, considering the probable higher geothermal gradient in the earlier stage of rifting as well as high organic carbon content, plenty of methane is expected to have been produced upon burial, migrated upward, and oxidized by sulfate in the near-surface sediments, thus increasing the alkalinity of the anaerobic methane oxidation zone. These processes together dramatically increased the alkalinity of the near-surface sediments during late Miocene and Pliocene and probably account for the unusual lansfordite and magnesite found in Site 799 sediments.

\section{Precipitation and Recrystallization of Dolomite}

Figure 17 clearly demonstrates that dolomite layers occur in sediments with a slightly negative $\mathrm{Ce}$ anomaly or with "normal" Ce values of
$\mathrm{Ce} / \mathrm{Ce} *$ approximately 0.5 to 1.2 . The host sediments of the dolomite layers are, in most cases, either laminated or variably bedded and lack distinctive bioturbation and burrow features. Geochemical and lithologic evidence suggest that dolomite precipitation was favored by rather anoxic conditions. This is consistent with the conclusions of the previous studies on the origin of diagenetic dolomite in deep-sea sediments (e.g., Kelts and McKenzie, 1982; Baker and Burns, 1985). The mottled or bioturbated, oxic sediments in Units II and III contain some dolomite layers at $247.1,252.2,443.6$, and $465.8 \mathrm{mbsf}$. However, even these dolomites occur within or close to the sediments with negative to normal $\mathrm{Ce} / \mathrm{Ce}$ * values indicating anoxic condition; the dolomite layers at 247.1 and $252.2 \mathrm{mbsf}$ appear to correspond to a sharp drop in $\mathrm{Ce} / \mathrm{Ce} *$ values at about $230 \mathrm{mbsf}$, and layers at 443.6 and 465.8 mbsf to the drop between 450 and 500 mbsf (Fig. 17).

Continued bacterial sulfate reduction under anoxic conditions would effectively decrease the sulfate activity in the interstitial waters, resulting in a decrease of $\mathrm{Mg}^{2+}$ and $\mathrm{SO}_{4}^{2-}$ ion pairing and an increase of free $\mathrm{Mg}$ ions originally derived from seawater. Sulfate reduction within near-surface sediments effectively increases both alkalinity and bicarbonate concentrations, but, as discussed above, if the alkalinity becomes very high, $\mathrm{Mg}$ might be precipitated as hydrous Mg-carbonates but not as dolomite (or protodolomite?). Therefore, the alkalinity is considered to have been moderately high in the dolomite-rich horizons. The organic-carbon content ranges between about $1 \%$ and $2.5 \%$ for the dolomite-rich intervals below about 700 mbsf, which is approximately one-half of the sediments associated with the magnesite-rich layers between 400 and $650 \mathrm{mbsf}$ (Fig. 18).

Dolomite layers in Units IV and V commonly exhibit a few-millimeter, light-colored, sedimentary laminations (Fig. 4). The laminations are presently composed of coarse crystallized dolomite but were presumably originally laminar to lenticular concentrations of foraminifer tests. This conclusion is based on the analogy that these laminations are similar to the thin, yellowish, foraminifer sand layers observed in Unit I. The burial depth of recrystallization of biogenic carbonates is estimated to be about $400-500 \mathrm{mbs}$ based on the $\delta^{18} \mathrm{O}$ values.
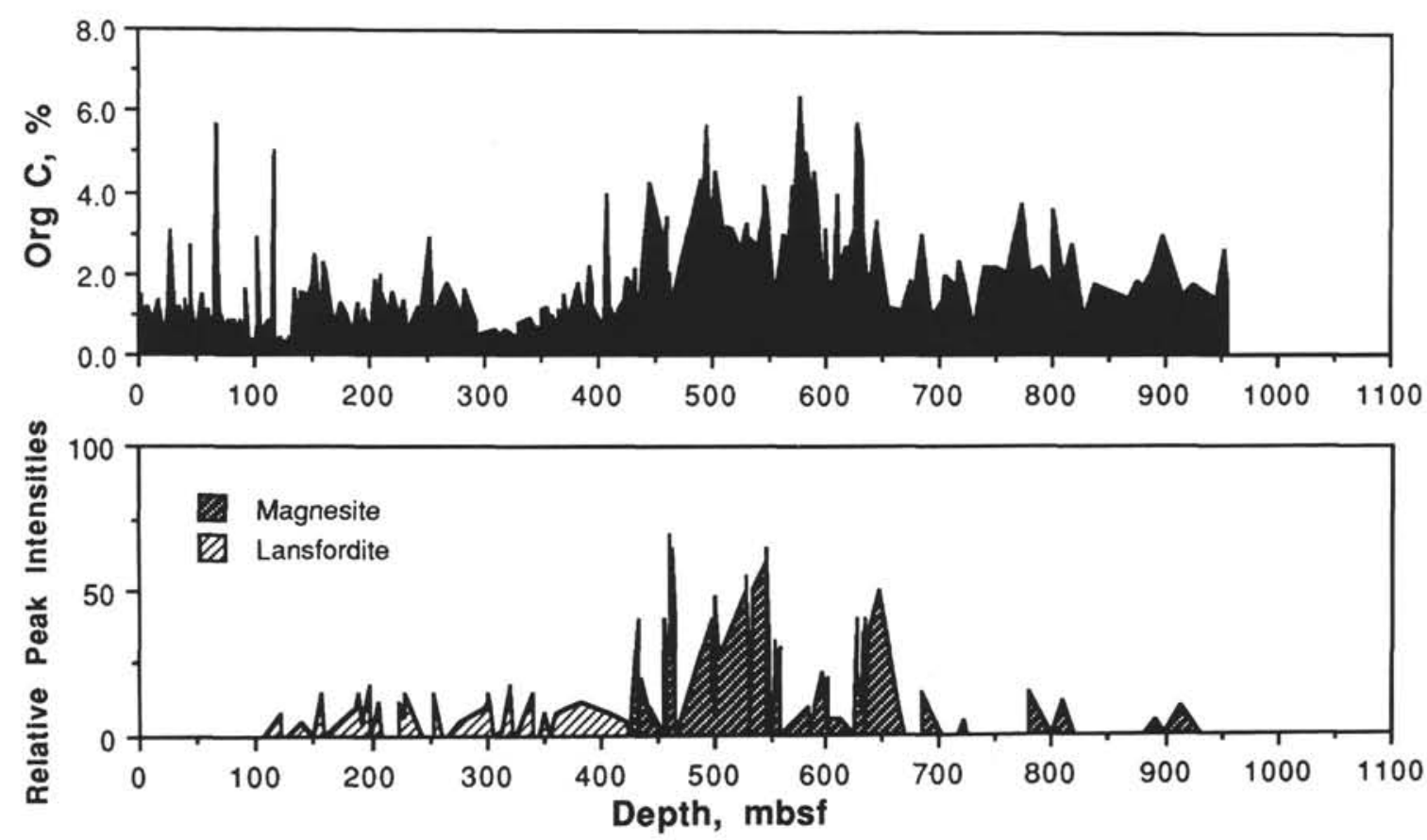

Figure 18. Relation between the carbonate mineralogy and organic carbon content at Site 799. Data from Shipboard Scientific Party (1990g). 
The depth of precipitation of Site 799 dolomite spans 100-581 mbsf as estimated from oxygen isotope composition. This interval is, however, not consistent with the model of dolomite precipitation discussed previously. This apparent disparity can be ascribed to the effect of recrystallization and reset of ${ }^{18} \mathrm{O}$ values. The dolomite bed at $247.1 \mathrm{mbsf}$ is made up of uncrystallized, crypto- to microcrystalline dolomite, containing well-preserved diatom frustules. Therefore, the $\delta^{18} \mathrm{O}$ values are considered to be original, and the estimated depth of precipitation, 60 to $130 \mathrm{mbsf}$, is regarded as the depth of initial precipitation. The chemical composition, approximately $50.5-51.5$ $\mathrm{mol} \% \mathrm{MgCO}_{3}, 50.5-51.0 \mathrm{~mol} \% \mathrm{CaCO}_{3}$, and $1-2.5 \mathrm{~mol} \%(\mathrm{Fe}+$ $\mathrm{Mn}) \mathrm{CO}_{3}$, represents the initial dolomite. Figure 19 shows that $(\mathrm{Fe}+$ $\mathrm{Mn}) \mathrm{CO}_{3}$ content tends to increase with the depth of precipitation. In this diagram, dolomites formed above $300 \mathrm{mbsf}$ are relatively poor in $\mathrm{Fe}$ and $\mathrm{Mn}$ and, in terms of recrystallization degree, are classified either as type A or B. This suggests that the zone of initial dolomite precipitation extends down to 300 mbsf. In contrast, those plotted below 300 mbsf are moderately to intensively recrystallized and there are increasing amounts of $\mathrm{Fe}$ and $\mathrm{Mn}$ substitution with depth. Thus, the depth of precipitation is not the depth of initial precipitation, but the depth of recrystallization. When recrystallization is incomplete, the estimated depth may represent the intermediate depth between initial precipitation and recrystallization, reflecting the effect of relic values. Dolomites in Unit IV were probably

\section{$(\mathrm{Fe}+\mathrm{Mn}) \mathrm{CO} 3$ IN DOLOMITE $(\mathrm{mol} \%)$}

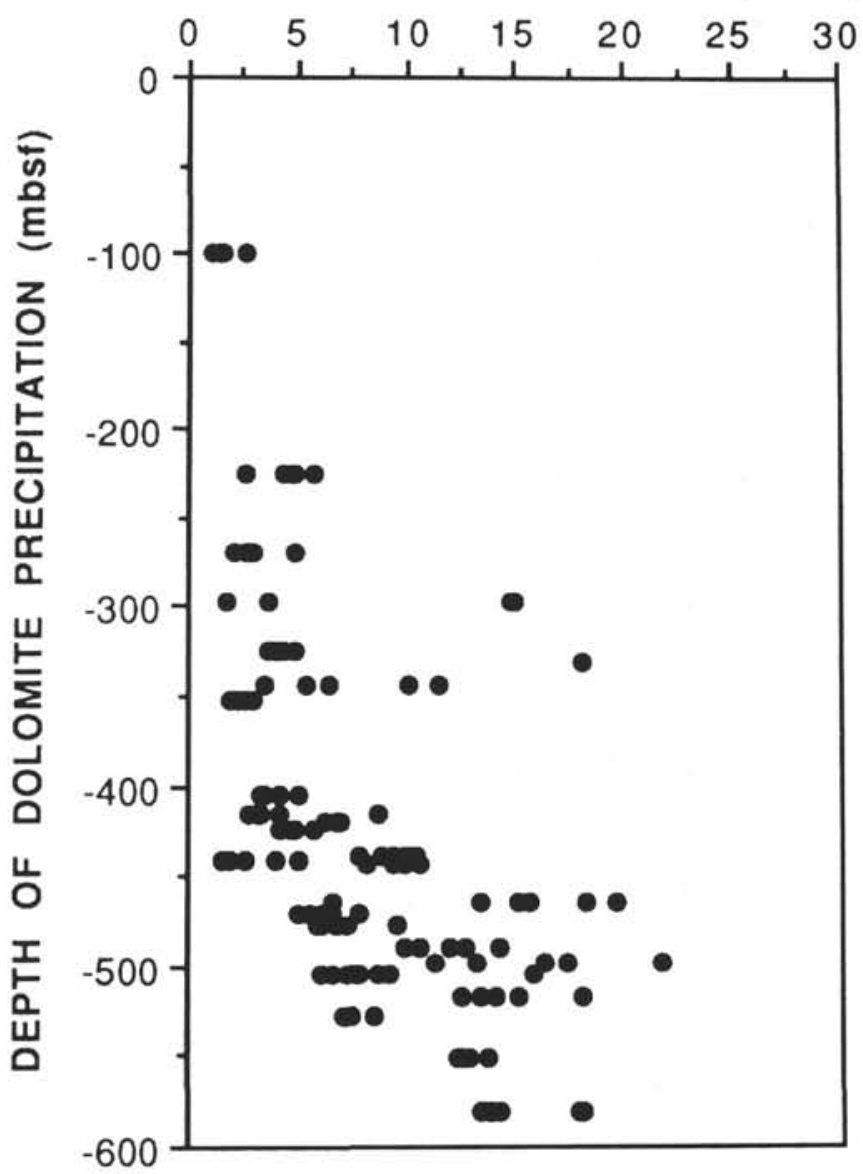

Figure 19. $(\mathrm{Fe}+\mathrm{Mn}) \mathrm{CO}_{3}$ content of dolomite-ankerite plotted against the depth of precipitation. Fe and Mn contents tend to increase with depth of precipitation or, more exactly, depth of recrystallization, reflecting the evolution of the interstitial-water chemistry. originally precipitated as low- $\mathrm{Fe}-\mathrm{Mn}$ protodolomite in the shallow, sulfate-reduction zone promoted by the high $\mathrm{Mg}$ concentrations from seawater, high $\mathrm{Ca}$ concentrations derived from biogenic carbonates and seawater, and high alkalinity due to organic matter decomposition through sulfate reduction. With an increasing depth of burial, the dolomites would be exposed to higher temperatures and isotopically and chemically different waters; textures and fabrics may change, and the chemical and isotopic compositions would be reequilibrated with the ambient waters at higher temperatures. The general increase in the amounts of $\mathrm{Fe}$ and $\mathrm{Mn}$ in dolomite-ankerite reported from a number of land locations (e.g., Murata et al., 1972; Matsumoto and Matsuda, 1987) and other DSDP/ODP sites (e.g., Matsumoto and Matsuhisa, 1980; Pisciotto and Mahoney, 1981) was explained as a result of a general increase in $\mathrm{Fe}$ and $\mathrm{Mn}$ concentrations of the interstitial waters with depth, as clearly demonstrated by shipboard measurements of the interstitial waters (Shipboard Scientific Party, 1990a, b, c, d, e, f, g).

The major zone of recrystallization at Site 799 is placed at about 400 to 600 mbsf. According to the shipboard interstitial water studies, $\mathrm{pH}$ values are constant between 7.5 and 8.0 for the depth interval of 0 and $250 \mathrm{mbsf}$, but rapidly decrease to as low as 5.0 at about $400 \mathrm{mbsf}$, and then recover to $7-8$ below $500 \mathrm{mbsf}$ (Fig. 20) (Shipboard Scientific Party, 1990a, f, g); Ca shows a somewhat sharp increase at about $500 \mathrm{mbsf}$, probably reflecting the dissolution of Ca-containing carbonate phases. Unusual acidic waters prevailing at about 400 mbsf may have triggered the recrystallization of dolomite. An unusual decrease in $\mathrm{pH}$ values recorded at Site 799 may have been caused by the thermocatalytic degradation of kerogen and the elevated concentration of short-chained carboxylic acid such as CH3COO- (Carothers and Kharaka, 1980; Surdam et al., 1984). The recovery of a fluorescent cut (slightly oil-stained sands) at the bottom of Hole 799B stopped drilling for safety reason. Providing that the geothermal gradient was higher during the Miocene than at present $\left(98^{\circ} \mathrm{C} / \mathrm{km}\right)$, the thermocatalytic degradation zone of Carothers and Kharaka (1980) would have occurred as shallow as 400 mbsf.

\section{Paleoenvironmental Implications of Diagenetic Carbonates}

Variations in mineralogy and chemistry of diagenetic carbonates in Site 799 sediments have been controlled primarily by the environment of deposition, especially in terms of oxidation-reduction state and alkalinity level, and original composition of the host sediments, particularly the manganese, magnesium, and organic carbon contents as schematically illustrated in Figure 21. The environmental parameters have determined the initial phases in which $\mathrm{Fe}, \mathrm{Mn}, \mathrm{Mg}$, and $\mathrm{Ca}$ should be incorporated and subsequent burial diagenesis modified, and transformed the initial phases to more stable phases and compositions. Thus the stratigraphically controlled distribution of various diagenetic carbonates (Fig. 8) may reflect both the changing environment of deposition and diagenetic modification.

The Units I and II sediments (Quaternary, late Pliocene, and late Miocene), exclusive of the top 100 -m-section with decimeter-thick, light/dark rhythms, are characterized by common to abundant rhodochrosite, subordinate but continual occurrence of lansfordite, and sporadic calcite. The abundant rhodochrosite is explained to have inherited from hydrogenous manganese in the oxic surface sediments, indicating the well-oxygenated bottom waters during this period.

The present seawater, particularly the bottom water of the Japan Sea, is well oxygenated probably due to an annual and massive sink of the cold water generated at the surface in the northern part of Japan Sea during winter (Gamo et al., 1986). The oxic bottom water has also been suggested by the positive $\mathrm{Ce}$-anomaly of the surface sediments at Site 799 as shown in Figure 17. Reflecting the oxic condition of the bottom water, the seafloor at water depths greater than $1600 \mathrm{~m}$ is mostly covered by brown to brick-red mud with high manganese content, $0.2 \%$ to $3.0 \% \mathrm{MnO}$, whereas the seafloor shallower than 


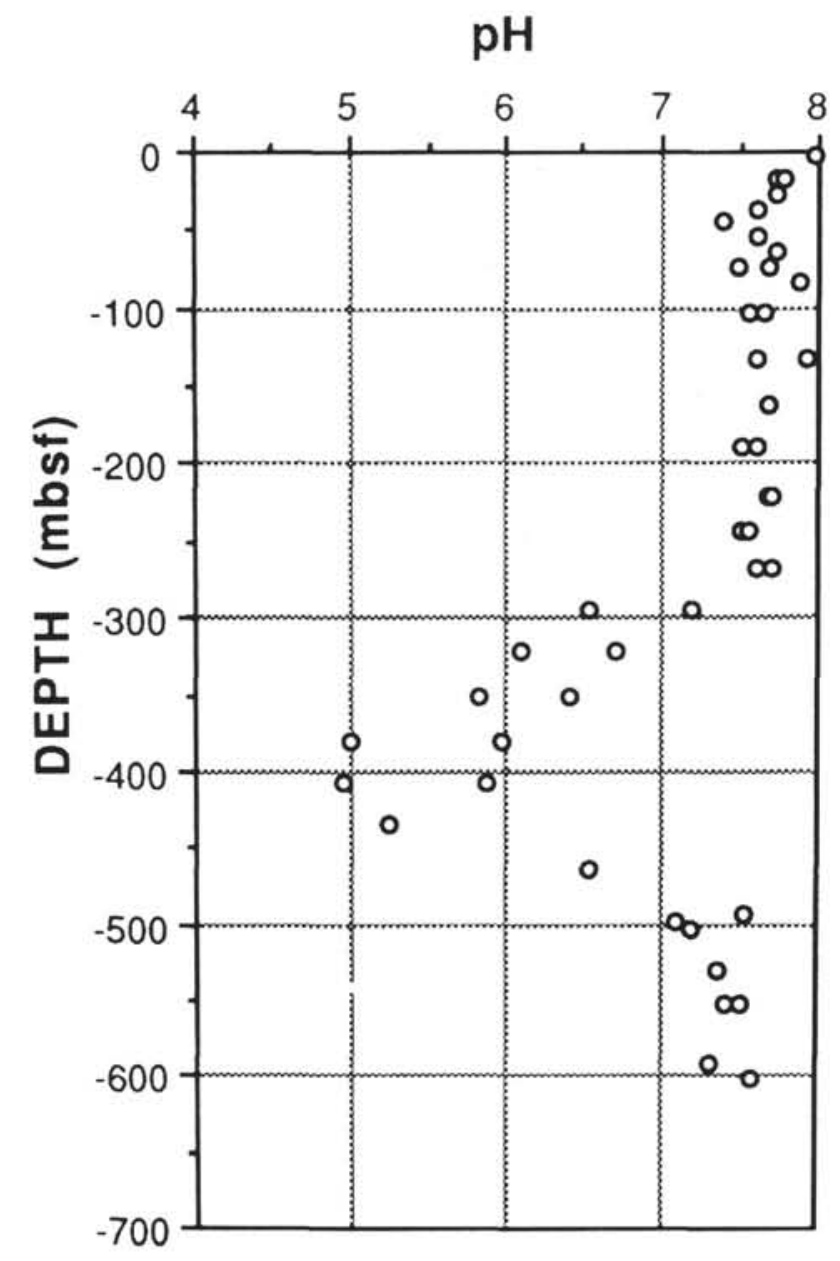

Figure 20. Depth profiles of $\mathrm{pH}$ in the interstitial waters at Site 799. The $\mathrm{pH}$ shows dramatic decrease to about 5.0 at 400 mbsf, which might have been caused by the thermocatalytic degradation of kerogen (Shipboard Scientific Party, 1990g).

about $1600 \mathrm{~m}$ is largely dominated by blue mud with $0.03 \%$ to $0.15 \% \mathrm{MnO}$ (Masuzawa, 1987), who also recognized a small amount of Mn-containing carbonate mineral in the near-surface sediments. The diagenetic processes occurring in the modern Japan Sea sediments are considered to be the modern analogue of the formative process of rhodochrosite in Units I and II. The rhodochrosite first occurs at about 100 mbsf, then the content appears to decrease with depth through the Units I, II, and III (Fig. 8). Assuming that the abundance of rhodochrosite is primarily controlled by the degree of the hydrogenous accumulation of manganese, the observed depth profile of rhodochrosite indicates that the bottom water condition became more and more oxic with time from the late Miocene through Pliocene to Quaternary, and that the condition suddenly returned to anoxic at about $1.5 \mathrm{Ma}$ when the dark/light rhythms began, presumably reflecting the commencement and development of the Quaternary glaciers. During this period, however, thin, manganese-rich oxic layers occur within the light-colored, bioturbated intervals.

The Unit III (late and middle Miocene), dominated by magnesite with occasional dolomite, rhodochrosite, and calcite, represents the transitional zone between the generally oxic (Unit II) and anoxic (Unit IV) conditions of the bottom waters. Rhodochrosite is common in the sediments at about 500,600 , and 650 mbsf with relatively high $\mathrm{Ce} / \mathrm{Ce}$ * ratios (1.3 to 1.7$)$, whereas the dolomitic layers tend to concentrate in the lower part between 700 and $800 \mathrm{mbsf}$, in which no rhodochrosite occurs and the $\mathrm{Ce} / \mathrm{Ce}$ * ratio decreases to 1.0 with depth. Discontinuous occurrence of and approximately negative correlation between rhodochrosite and dolomite in the Unit III may reflect that the bottom water condition fluctuated between oxic and anoxic several times during this period.

Magnesite and lansfordite are unusual carbonates, particularly in normal marine sediments; hence, the Unit III sediments must have experienced anomalous environmental conditions with extremely high alkalinity level, which can probably be ascribed to the high content of organic carbon of this Unit. Significantly, the magnesite-rich interval, approximately between 450 and $650 \mathrm{mbsf}$, is anomalously enriched in organic carbon too. Decomposition of the abundant organic carbon by sulfate reduction and anaerobic oxidation of the upward-migrating methane might have dramatically increased the alkalinity in the near-surface sediments. Presumably higher geothermal gradients in the Miocene might have accelerated the thermal degradation of organic matter and contributed to increasing the alkalinity.

Unit IV (early and middle Miocene) is a zone of dolomite formation with trace amounts of magnesite, rhodochrosite, and calcite. Characteristic parallel laminations, no bioturbation, high organic carbon content (approx. $2 \%-3 \% \mathrm{C}_{\mathrm{org}}$ ), and the $\mathrm{Ce} / \mathrm{Ce} *$ ratios of $1.0 \pm 0.25$ indicate that both the bottom waters and the sediments are generally anoxic. Under these conditions, the sulfate reduction in the near-surface sediments were accelerated and the alkalinity and bicarbonate concentration of the interstitial water were increased. The increased alkalinity and decreased sulfate concentration in the sulfate reduction zone, together with the modest supply of $\mathrm{Ca}$ from the sporadic biogenic carbonates and negligible amount of the hydrogenous manganese, promoted the precipitation of protodolomite in the near-surface sediments. Dolomite precipitation continued down to a few hundred meters, depending on the rate of sulfate reduction and available $\mathrm{Mg}$ derived from the overlying seawater. At about 400 mbsf, unstable protodolomite was exposed to unusual acidic waters derived from kerogen maturation as well as to elevated temperatures, and it partly dissolved and recrystallized. $\mathrm{Mg}$, liberated from the decomposition of lansfordite at about $440 \mathrm{mbsf}$, possibly played an important role in the precipitation of well-ordered dolomite at this depth. Fe and especially $\mathrm{Mn}$, which were originally contained as either oxides or lansfordite, were incorporated into well-ordered dolomite during recrystallization, reflecting the increased concentrations of $\mathrm{Fe}$ and $\mathrm{Mn}$ with depth.

\section{CONCLUSIONS}

The following conclusions derive from the combined results of petrographical and geochemical analyses of the sediments from Site 799:

1. Variation in mineralogy of diagenetic carbonates at Site 799 has been determined by the near-surface processes such as (1) hydrogenous accumulation of manganese on the seafloor, (2) precipitation of hydrous $\mathrm{Mg}$ carbonate (lansfordite) under extremely high alkalinity conditions, and (3) protodolomite precipitation in the anoxic, moderately biocalcareous sediments.

2. During the late Miocene to early Quaternary (Lithologic Units I and II), oxygenated bottom waters prevailed in the KitaYamato Trough, and a significant amount of manganese was initially precipitated from seawater as hydrogenous oxides and formed a brown to red colored, Mn-rich layer on the seafloor. With burial, Mn oxides were reduced to produce $\mathrm{Mn}^{2+}$, which in turn was precipitated as rhodochrosite within the sulfate reduction zone.

3. The middle to late Miocene (Unit III) represents the transition between generally oxic Pliocene (Unit II) and anoxic early to early middle Miocene (Unit IV). Unit III sediments are characterized by extremely high rates of accumulation of organic carbon, probably 
Well oxygenated
oxic bottom waters

Well oxygenated
oxic bottom waters
Higher surface productivity

Diatoms Diatoms+Forams+Nannos

Hydrogenous accumulation of manganese and iron

Anoxic bottom waters

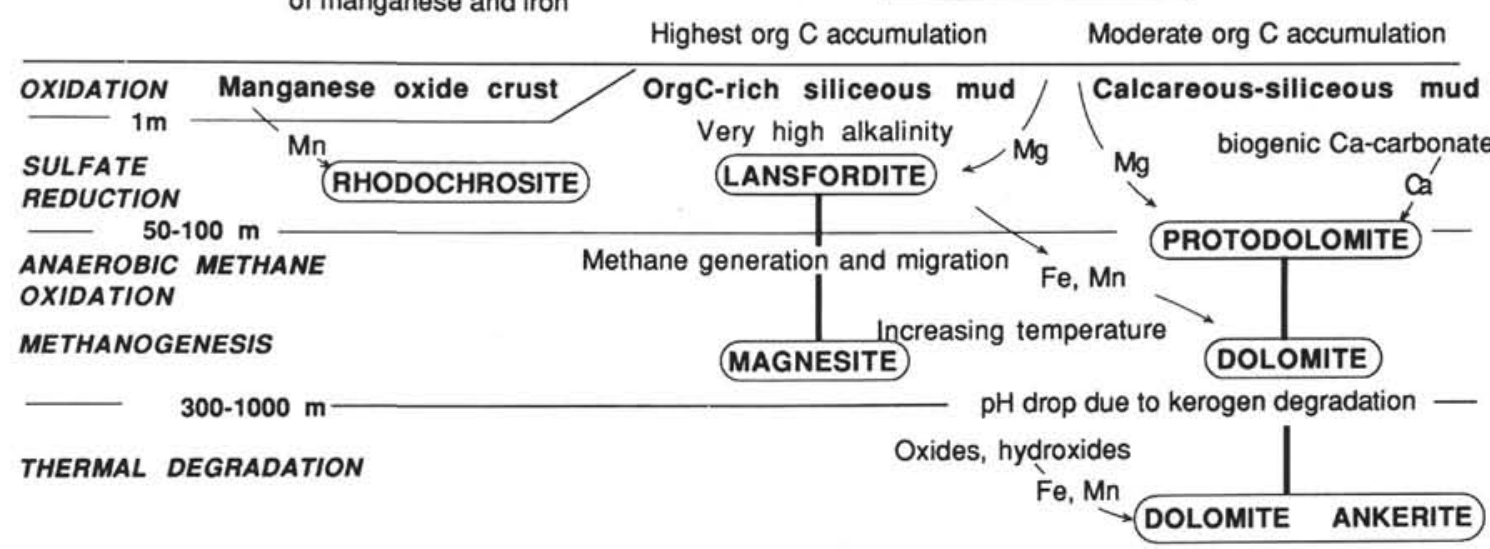

Figure 21. Schematic illustration showing the environmental implications of diagenetic carbonates at Site 799. Thick lines indicate transformation-recrystallization with burial.

reflecting high surface productivity and less oxic bottom water conditions. The alkalinity increased to extremely high levels, probably due to massive consumption of organic matter in a moderately oxic to anoxic environment. $\mathrm{Mg}$, which originated in seawater, was first precipitated as lansfordite, not as dolomite, because the alkalinity was too high to precipitate dolomite. With continued burial and elevated temperatures, metastable lansfordite was transformed to magnesite at about 440 mbsf.

4. In an anoxic environment of the early to early middle Miocene (Units IV and V), Mg derived from the overlying seawater and $\mathrm{Ca}$ from biogenic carbonate precipitated to form dolomite (protodolomite?) in the sulfate reduction, anaerobic methane oxidation, and methanogenesis zones of moderately biocalcareous sediments. Protodolomite was recrystallized in equilibrium with evolved interstitial waters below $400 \mathrm{mbsf}$ at elevated temperatures. Chemical and isotopic signatures were entirely reset by recrystallization. A dramatic decrease in $\mathrm{pH}$ values down to approximately $4.5-5.0$ caused by degradation of kerogen may have accelerated the dolomite recrystallization.

\section{ACKNOWLEDGMENTS}

The author thanks Judith McKenzie of ETH Zentrum and Max Coleman of BP International Limited for their constructive comments and discussions. This research has been supported by Grant-in-Aid from the Ministry of Education and Culture (Grant Nos. 01540625 and 03543054 , R. Matsumoto).

\section{REFERENCES}

Alderman, A. R., 1965. Dolomitic sediments and their environment in the South-East of South Australia. Geochim. Cosmochim. Acta, 29:1335-1365.

Baker, P., and Burns, S. J., 1985. The occurrence and formation of dolomite in organic-rich continental margin sediments. AAPG. Bull., 69:1917-1930.

Bohrmann, G., and Thiede, J., 1989. Diagenesis in Eocene claystones, ODP Site 647, Labrador Sea: formation of complex diagenetic carbonates, smectite, and apatite. In Srivastava, S. P., Arthur, M., Clement, B., et al., Proc. ODP, Sci. Results, 105: College Station, TX (Ocean Drilling Program), 137-154.

Burkle, L. H., and Akiba, F., 1978. Implications of late Neogene freshwater sediments in the Sea of Japan. Geology, 6:123-127.
Carothers, W. W., and Kharaka, Y. K., 1978. Aliphatic acid anions in oil-field waters-implications for origin of natural gas. AAPG Bull., 62:2441-2453.

Claypool, G. E., and Threlkeld, C. N., 1983. Anoxic diagenesis and methane generation in sediments of the Blake outer ridge DSDP Site 533, Leg 76. In Sherian, R. E., Gradstein, F. M., et al., Init. Repts. DSDP, 76: Washington (U.S. Govt. Printing Office), 391-407.

Curtis, C. D., and Coleman, M. L., 1986. Controls on the precipitation of early diagenetic calcite, dolomite, and siderite concretions in complex depositional sequences. In Gautier, D. L. (Ed.), Roles of Organic Matter in Sediment Diagenesis. Spec. Publ.-Soc. Econ. Paleontol. Mineral., 38:23-33.

Friedman, I., and O'Neil, J. R., 1977. Compilation of stable isotope fractionation factors of geochemical interest. Geol. Surv. Prof. Pap. U.S., 440-KK:1-12.

Fritz, P., and Smith, D.C.W., 1970. The isotopic composition of secondary dolomites. Geochim. Cosmochim. Acta., 34:1161-1173.

Gamo, T., Nozaki, Y., Sakai, H., Nakai, T., and Tsubota, H., 1986. Spacial and temporal variations of water characteristics in the Japan Sea bottom layer. J. Mar. Res., 44:781-793.

Garrison. R. E., and Graham, S. A., 1984. Early diagenetic dolomites and the origin of dolomite-bearing breccia, Lower Monterey Formation, Arroyo Seco, Monterey County, California. In Garrison, R. E., Kastner, M., and Zenger, D. H. (Eds.), Dolomites of the Monterey Formation and Other Organic-Rich Units. Soc. Econ. Paleontol. Mineral., Pac. Sect., 87-102.

Hudson, J. D., 1977. Stable isotopes and limestone lithifications. J. Geol., 133:637-660.

Irwin, H., Curtis, C. D., and Coleman, M., 1977. Isotopic evidence for source of diagenetic carbonates formed during burial of organic-rich sediments. Nature, 269:209-213.

Kastner, M., Mertz, K., Hollander, P., and Garrison, R., 1984. The association of dolomite-phosphorite-chert: causes and possible diagenetic sequences. In Garrison, R. E., Kastner, M., and Zenger, D. H. (Eds.), Dolomites of the Monterey Formation and Other Organic-Rich Units. Soc. Econ. Paleontol. Mineral, Pac. Sect., 75-86.

Kelts, K., and McKenzie, J. A., 1982. Diagenetic dolomite formation in Quaternary anoxic diatomaceous muds of Deep Sea Drilling Project Leg 64, Gulf of California. In Curry, J. R., Moore, D. G., et al., Init. Repts. DSDP, 64 (Pt.2): Washington (U.S. Govt. Printing Office), 553-569.

Lippmann, F., 1973. Sedimentary Carbonate Minerals: Berlin (Springer Verlag).

Masuzawa, T., 1987. Early diagenesis in deep-sea sediments of the Japan Sea: type, controlling factor, and diffusive flux. J. Earth Sci. Nagoya Univ., $35: 249-267$.

Matsumoto, R., and Matsuda, H., 1987. Occurrence, chemistry, and isotopic composition of carbonate concretions in the Miocene to Pliocene siliceous 
sediments of Aomori, northeast Japan. J. Fac. Sci., Univ. Tokyo, Sect. 2, 21:351-377.

Matsumoto, R., and Matsuhisa, Y., 1985. Chemistry, carbon and oxygen isotope ratios, and origin of deep-sea carbonates at Sites 438, 439, and 584: inner slope of the Japan Trench. In Kagami, H., Karig, D. E., and Coulburn, W. C., Init. Repts. DSDP, 87: Washington (U.S. Govt. Printing Office), 669-678.

McCrea, J. M., 1950. On the isotopic chemistry of carbonates and a paleotemperature scale. J. Chem. Phys., 18:849-857.

Müller, G., Irion, G., and Forstner, U., 1972. Formation and diagenesis of inorganic $\mathrm{Ca}-\mathrm{Mg}$ carbonates in the lacustrine environment. Naturwissenschaften, 59:158-164.

Murata, K. J., Friedman, I., and Cremer, M., 1972. Geochemistry of diagenetic dolomites in Marine formations of California and Oregon. U.S. Geol. Surv. Prof. Pap., 724-C.

Murata, K. J., Friedman, I., and Madsen, B. M., 1969. Isotopic composition of diagenetic carbonates in marine Miocene formation of California and Oregon. U.S. Geol. Surv. Prof. Pap., 614-B.

Ohmori,T., 1991. Effects of phosphate-containing compounds on magnesian calcite formation. Abstr. Ann. Meet. Geochem. Soc. Jpn., Niigata Univ.

O'Neil, J. R., 1977. Stable isotopes in mineralogy. Phys. Chem. Mineral., 2:105-123.

O'Neil, J. R., Clayton, R. N., and Mayeda, T. K., 1969. Oxygen isotopic fractionation in divalent metal carbonates. J. Chem. Phys., 51:5547-5548.

Pisciotto, K. A., and Mahoney, J. J., 1981. Isotopic survey of diagenetic carbonates, Deep Sea Drilling Project, Leg 63. In Yeats, R. S., Haq., B. U., et al., Init. Repts. DSDP, 63: Washington (U.S. Govt. Printing Office), 595-609.

Pueyo, M.J.J., and Ingles Urpinell, M., 1987. Magnesite formation in recent playa lakes, Los Monegros, Spain. In Marshall, J. D. (Ed.), Diagenesis of Sedimentary Sequences. Geol. Soc. Spec. Publ. London, 36:119-122.

Raiswell, R., 1987. Non-steady state microbiological diagenesis and the origin of concretions and nodular limestones. In Marshall, J. D. (Ed.), Diagenesis of Sedimentary Sequences. Geol. Soc. Spec. Publ. London, 36:41-54.

Shipboard Scientific Party, 1990a. Site 794. In Ingle, J. C., Jr., Suyehiro, K., von Breymann, M. T., et al., Proc. ODP, Init. Repts., 128: College Station, TX (Ocean Drilling Program), 67-120.

, 1990b. Site 794. In Tamaki, K., Pisciotto, K., Allan, J., et al., Proc. ODP, Init. Repts., 127: College Station, TX (Ocean Drilling Program), 71-167.

, 1990c. Site 795. In Tamaki, K., Pisciotto, K., Allan, J., et al., Proc. ODP, Init. Repts., 127: College Station, TX (Ocean Drilling Program), $169-245$. 1990d. Site 796. In Tamaki, K., Pisciotto, K., Allan, J., et al., Proc ODP, Init. Repts., 127: College Station, TX (Ocean Drilling Program), 247-322.

, 1990e. Site 797. In Tamaki, K., Pisciotto, K., Allan, J., et al., Proc. ODP, Init. Repts., 127: College Station, TX (Ocean Drilling Program), 323-421.

1990f. Site 798. In Ingle, J. C., Jr., Suyehiro, K., von Breymann, M. T., et al., Proc. ODP, Init. Repts., 128: College Station, TX (Ocean Drilling Program), 121-236.

, 1990g. Site 799. In Ingle, J. C., Jr., Suyehiro, K., von Breymann, M. T., et al., Proc. ODP, Init. Repts., 128: College Station, TX (Ocean Drilling Program), 237-402.

Shepard, S.M.F., and Schwarz, H. P., 1970. Fractionation of carbon and oxygen isotopes and magnesium between metamorphic calcite and dolomite. Contrib. Mineral. Petrol., 26:161-198.

Surdam, R. C., Boese, S. W., and Crossey, L. J., 1984. The geochemistry of secondary porosity. In McDonald, D. A., and Surdam, R. C. (Eds.), Clastic Diagenesis. AAPG Mem., 37:127-149.

Taguchi, K., Kana, K., and Hayashida, N., 1980. Carbonate nodules with manganese crust found in the Neogene Tertiary of the Kameda oil field, northeast Japan. J. Geol. Soc. Jpn., 86:545-553.

Tarutani, T., Clayton, R. N., and Mayeda, T. K., 1969. The effect of polymorphism and magnesium substitution on oxygen isotope fractionation between calcium carbonate and water. Geochim. Cosmochim. Acta, 33:987-996.

von Rad, U., and Botz, R., 1987. Diagenetic Fe-Mn carbonates in the Cretaceous and Tertiary continental rise sediments of DSDP Sites 603 off the eastern U.S.A. In van Hinte, J. E., Wise, S. W., Jr., et al., Init. Repts. DSDP, 93: Washington (U.S. Govt. Printing Office), 1061-1077.

Wada, H., Niitsuma, N., Nagasawa, K., and Okada, H., 1982. Deep-sea carbonate nodules from the Middle America Trench area off Mexico, Deep Sea Drilling Project Leg 66. In Watkins, J. S., Moore, J. C., et al., Init. Repts. DSDP, 66: Washington (U.S. Govt. Printing Office), 453-474.

Date of initial receipt: 18 March 1991

Date of acceptance: 9 December 1991

Ms 127/128B-119 

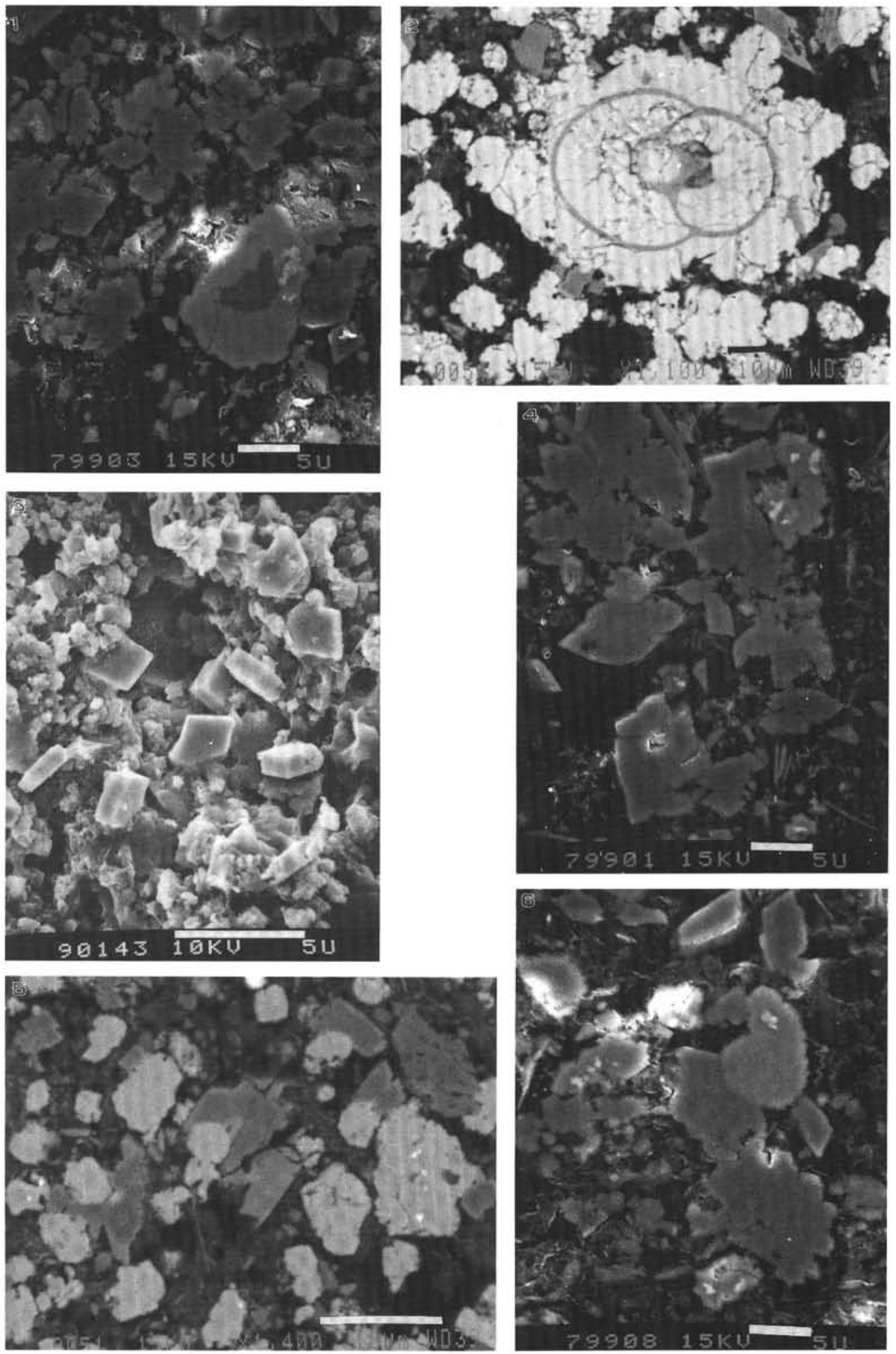

Plate 1. Scanning electron micrographs. 1. Polished surface of a rhodochrosite-magnesite bed, showing light-colored, microspherulitic rhodochrosite with sporadic pyrite and apatite(?) inclusions (lower right) and rhombohedral crystals of ferroan magnesite. $($ Sample $128-799 \mathrm{~B}-11 \mathrm{R}-5,100-104 \mathrm{~cm})$. Scale bar $=$ $5 \mu \mathrm{m}$. 2. Composite rhodochrosite spherule growing over a foraminifer test (Sample 128-799B-18R-5, $5-8 \mathrm{~cm}$ ). Polished surface. Scale bar $=10 \mu \mathrm{m}$. 3. The fractured surface of a magnesite bed showing sharp-edged rhombohedral magnesite crystals (Sample 128-799B-36R-1, 84-89 cm). Scale bar $=5 \mu \mathrm{m}$. 4. The polished surface of rhodochrosite-magnesite bed (Sample 128-799B-11R-5, 100-104 cm). Scale bar $=5 \mu \mathrm{m}$. 5. The polished surface of rhodochrosite-magnesite layer (Sample 128-799B-18R-5, 5-8 cm). Note that the rhodochrosite microspherules are overgrown and included by rhombohedral magnesite crystals. Scale bar $=20 \mu \mathrm{m}$. 6. The polished surface showing the textural relation between rhodochrosite spherules and magnesite rhombohedra (128-79B-11R-5, 100-105 $\mathrm{cm})$. Scale bar $=5 \mu \mathrm{m}$. 

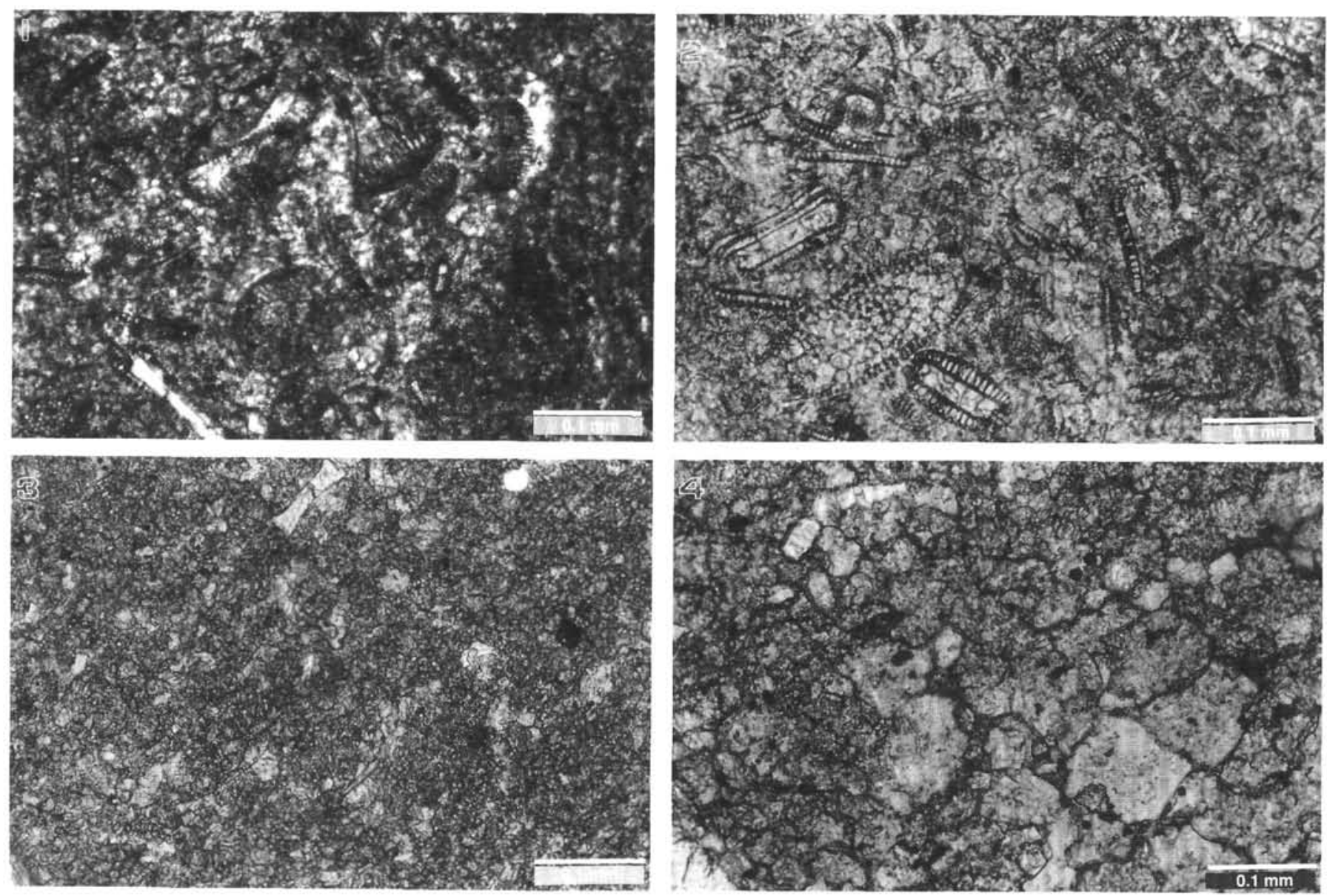

Plate 2. Microphotographs of dolomite beds. 1, 2. Sample 128-799A-28X-1,4-12 cm. 3. Sample 128-799B-31R-1,37-47 cm. 4. Sample 128-799B-63R-1, $110-118 \mathrm{~cm}$ ). Figure 1 and 2 (type A) show well-preserved diatom frustules, composed of micro to medium crystallized dolomite crystals. Figure 3 displays the texture of type B dolomite, composed of recrystallized dolomite grains 10-50 $\mu \mathrm{m}$ in diameter. Diatom frustules are very few but some remains are still visible. Figure 4 shows typical textures of type $\mathrm{C}$ dolomite, intensively recrystallized; sedimentary structures and diatoms have been entirely obliterated. 